\title{
Governance and Equity Prices: Does Transparency Matter?*
}

\author{
LIFENG GU and DIRK HACKBARTH \\ College of Business, University of Illinois at Urbana-Champaign
}

\begin{abstract}
This article examines how accounting transparency and corporate governance interact. Firms with better governance are associated with higher abnormal returns, but even more so if they also have higher transparency. The effect is largely monotonic - it is small and insignificant for opaque firms and large and significant for transparent firms - and survives numerous robustness tests. We find supportive evidence for firm value and operating performance. Hence, governance and transparency are complements. This complementarity effect is consistent with the view that more transparent firms are more likely takeover targets, because acquirers can bid more effectively and identify synergies more precisely.
\end{abstract}

JEL Classification: G30, G34

\section{Introduction}

Since Jensen and Meckling (1976), economists have devoted much effort in studying a firm's governance that balances the allocation of power between managers and shareholders, and a firm's information environment that provides shareholders with the data necessary to assess their firm's performance. Clearly, corporate governance and accounting transparency are not only important for academics and managers, but also for regulators. Recent cases of poor governance as, e.g., in the scandals of Enron or Worldcom, lead legislators to mandate new rules that enforce more transparency, suggesting governance and transparency are regarded as substitutes. Accordingly, the need to provide managers with incentives through governance - and thus the benefits of governance - should be smaller for more transparent firms.

\footnotetext{
*We are very grateful to the anonymous referee, Vyacheslav Fos, Radhakrishnan Gopalan, Todd Gormley, Mathias Kronlund, Christian Leuz, Xiumin Martin, Vijay Yerramilli, Xiaoyun $\mathrm{Yu}$, and seminar participants at the University of Illinois for thoughtful comments and suggestions. We are especially grateful to Martijn Cremers for providing us with data on the takeover factor.
} 
Gompers, Ishii, and Metrick (2003, GIM) propose takeover vulnerability as a one specific governance measure and construct the G-index, which consists of 24 anti-takeover and shareholder rights provisions. In their seminal article, GIM uncover an important link between governance and firm performance, since a long-short portfolio that buys good governance firms ("Democracy firms") and sells weak governance firms ("Dictatorship firms") earns a monthly abnormal return of $0.71 \%$. Based on these authors' work, a rich literature has emerged to examine various aspects that explain or even strengthen the effect of governance mechanisms on firm performance. ${ }^{1}$

Apart from the aforementioned anecdotal evidence, we know very little about how governance and transparency are related to firm's performance. This article focuses on a more specific question: are firms with better governance (measured by a lower G-index) associated with better performance, on average, if they are also more transparent (e.g., measured by lower forecast dispersion) $?^{2}$

To answer this question, we study the joint effect of a firm's information environment (or transparency) and its governance on equity returns. We use the G-index developed by GIM to proxy for a firm's governance and measure a firm's information environment by three transparency proxies: forecast error, forecast dispersion, and revision volatility. ${ }^{3}$ Every year, we divide GIM's "Democracy firms" (with strong corporate governance) and "Dictatorship firms" (with weak corporate governance) into three equal-sized portfolios based on whether the value of an analyst variable is

\footnotetext{
1 See, e.g., Cremers and Nair (2005), Core, Guay, and Rusticus (2006), Ferreira and Laux (2007), Cremers, Nair, and Peyer (2008), Bebchuk, Cohen, and Ferrell (2009), Cremers, Nair, and John (2009), and Giroud and Mueller (2011).

2 On the one hand, there is evidence on a positive association between governance and transparency at the international level (see, e.g., Bushman, Piotroski, and Smith, 2004; Leuz and Oberholzer, 2006; Doidge, Karolyi, and Stulz, 2007; Lang et al., 2012). On the other hand, Armstrong, Balakrishnana, and Cohen (2012) document for US firms affected by state anti-takeover laws between 1985 and 1991 that their information environment improves when protection from hostile takeovers increases, but they do not study firm performance. Yet, there is no reliable relation between governance and transparency in our sample of US firms (see Section 3.2), which is consistent with other studies (see, e.g., Larcker, Richardson, and Tuna, 2007). Finally, Hermalin and Weisbach (2007) argue the relation between governance and transparency is more subtle than previously believed. See Section 2 for theoretical arguments and testable hypotheses.

3 These are all standard measures used frequently by researchers in finance and accounting (see, e.g., Givoly and Lakonishok, 1979; Lang and Lundholm, 1996; Thomas, 2002; Zhang, 2006). Importantly, using accruals quality to measure transparency instead reinforces the interpretation of our findings, as the economic effects are stronger.
} 
in the lowest, medium, and highest tercile of its empirical distribution. The GIM-based trading strategy (or hedge portfolio) buys good governance firms and sells bad governance firms in each of the three terciles. To compare the success of the trading strategy across transparency terciles, we follow standard practice and compute returns of the "DemocracyDictatorship" hedge portfolio adjusted for the Carhart (1997) four-factor model within each of the transparency terciles.

Our main finding is that governance and transparency reinforce each other in that transparent firms benefit more from good corporate governance than opaque firms. Specifically, we find that the hedge portfolio in the high transparency tercile earns a high and significant abnormal return over the sample period, the hedge portfolio in the medium tercile earns a small and insignificant (or marginally significant) abnormal return, and the hedge portfolio in the low transparency tercile earns a smaller and insignificant abnormal return. This pattern applies to each of the three measures of transparency and survives using various deflators of the transparency proxies (i.e., share price, book assets per share, and absolute value of forecast mean). Moreover, when we combine all the information contained in forecast error, forecast dispersion, and revision volatility by constructing their 1st principal component and use the computed factor as a proxy for a firm's information environment, the hedge portfolio focusing on transparent firms earns a monthly alpha of $1.37 \%$ with $t$-statistic of 3.52 for value-weighted (1.28\% with $t$-statistic of 3.50 for equal-weighted) portfolios, which is nearly twice as large as the abnormal return on governance reported by GIM, whereas the monthly abnormal return of the hedge portfolio focusing on opaque firms is $0.04 \%$ with $t$-statistic of 0.09 for value-weighted $(0.04 \%$ with $t$-statistic of 0.11 for equal-weighted) portfolios. ${ }^{4} \mathrm{We}$ find similarly strong results when using each of the three transparency proxies individually and when scaling them by lagged assets per share, lagged share price, or absolute value of forecast mean. Our result also holds even if we employ timeinvariant sample averages of the transparency proxies, which are largely outside of the managers' discretion and hence more permanent firm characteristics, to construct transparency terciles only once instead of rebalancing them annually. The complementary effect between transparency and governance is also confirmed by profitability measures, such as return on assets

\footnotetext{
4 This finding for abnormal returns is not inconsistent with the fact that more transparent firms have, on average, a lower cost of equity capital (see, e.g., Leuz and Verrechia, 2000; Hail and Leuz, 2009; Botosan and Plumlee, 2002). For instance, the monthly equal-weighted portfolio return is, on average, $1.25 \%$ for the lowest, $1.35 \%$ for the medium, and $1.54 \%$ for the highest tercile of forecast dispersion in our sample during the 1990-2006 period.
} 
(ROA), return on equity (ROE), and net profit margin (NPM). We find that the positive relation between good corporate governance and operating performance is significant only when firms are transparent. ${ }^{5}$

Consistent with our main result, we find support for the view that transparency facilitates takeovers by comparing average transparency levels of target firms and all firms in the sample over the 1990-2006 period and by estimating an empirical logit model for takeover probability. In the latter case, only good governance firms, which are transparent, are more likely takeover targets. ${ }^{6}$

Our main finding survives numerous robustness tests. We replace the three transparency proxies by accruals quality and find that the economic magnitude of the Democracy-Dictatorship portfolio's abnormal returns for transparent firms increases. Next, we replace G-index by an alternative governance measure (i.e., the E-index), exclude "new economy" firms from the sample, and extend the sample period to 2011. In all cases, the results are consistent with our main finding. We also experiment by dividing the full sample into high- and low institutional ownership subsamples or into highand low industry competition subsamples. These additional tests not only support our hypothesis, but also are consistent with the findings in Cremers and Nair (2005) and Giroud and Mueller (2011). ${ }^{7}$ Moreover, we re-estimate alphas when splitting the sample at median asset size and median leverage ratio to verify that the main result is not largely due to these firm characteristics. Given that smaller firms and firms with less leverage are relatively easier to acquire, our main finding's interpretation is also confirmed because the Democracy-Dictatorship portfolio earns higher abnormal returns in the small firm and the low leverage subsamples. If a large part of the Democracy portfolio is composed of firms from high abnormal return industries and a large part of the Dictatorship portfolio is formed by firms from low abnormal return industries, then this could blur our identification. We dissolve this concern by using industry-adjusted returns with different asset pricing models. In addition, we provide an integrated test to establish the unique ability of transparency to influence abnormal returns of the Democracy-Dictatorship portfolio using multivariate regression analysis,

\footnotetext{
5 Complementing and reinforcing our results, Mukherjee (2011) shows that shareholder rights have a positive effect on performance when shareholders possess the information needed to enforce those rights (i.e., for transparent firms).

${ }^{6} \mathrm{Gu}$ (2012) includes forecast error, forecast dispersion, and revision volatility as additional predicting variables of takeover probability and finds that opacity (e.g., higher forecast dispersion) reliably reduces takeover probability.

7 See also, Hou and Robinson (2006), who find higher abnormal returns for firms in competitive industries than firms in noncompetitive industries.
} 
which allows us to control simultaneously for various variables used in prior research, such as competition, institutional ownership, etc. Finally, we experiment with alternative asset pricing models that include, e.g., the liquidity factor of Pastor and Stambaugh (2003) or the takeover factor of Cremers, Nair, and John (2009) as a 5th factor. Therefore, we conclude that a firm's information environment is an independently important dimension for the way in which corporate governance affects firm performance.

We obtain similar patterns when we examine the impact of corporate governance on firm value and operating performance. That is, good governance is significantly positively associated with firm value and operating performance, but only among transparent firms. For opaque firms, the effect is always small and insignificant. To shed light on the channel through which good governance in transparent firms creates value, we investigate corporate investment activities. We find that firms with good governance and high transparency have less capital expenditures and engage in less acquisition activities. Considerable evidence in the literature shows a negative announcement return and a negative abnormal performance by acquiring firms. Hence, these results permit the interpretation that good governance in transparent firms creates value by reducing agency costs.

The rest of the article is organized as follows. The next section discusses theoretical arguments and testable hypotheses. Section 3 provides details of the data source, variable definition, and summary statistics. Sections 4 and 5 examine the impact of corporate governance on stock returns. Our main results and robustness checks are, respectively, presented in these sections. Section 6 examines the relation between governance, firm value, and operating performance. Section 7 concludes.

\section{Theoretical Arguments and Testable Hypotheses}

In this section, we provide theoretical arguments for how governance and transparency can influence equity prices (or performance) and develop three competing testable hypotheses.

To begin, the need to provide managers with incentives through governance could be smaller for more transparent firms, because outside investors more easily monitor their actions (e.g., Shleifer and Vishny, 1997). Similarly, more opaque firms lack the scrutiny of outside investors that disciplines their managers and hence they should benefit relatively more from governance. Put differently, transparency and governance are substitutes if higher transparency enhances mainly the monitoring role played by the shareholders and the market, which in turn reduces managerial slack and maximizes firm 
performance. Since corporate governance also disciplines management, these two channels duplicate each other's positive effect on management and hence performance. Accordingly, firms with low transparency and, at the same time, fewer anti-takeover and shareholder rights provisions will, all else equal, benefit more from corporate governance than firms with high transparency.

Moreover, in less transparent environments, where managers also face riskier outcomes to their decisions and monitoring costs for outsiders are high (Demsetz and Lehn, 1985), monitoring by outsiders is relatively inefficient. Indeed, Hermalin and Weisbach (1988) find lower transparency makes the option to replace managers less valuable. If governance is a substitute for monitoring managers (i.e., reduces the likelihood of having to replace managers), then the inefficiencies due to low transparency should be lower for well-governed firms, suggesting again that governance and transparency should be substitutes in terms of their influence on firm performance. As a result, the positive effect of governance on returns should be stronger for opaque than transparent firms.

In contrast, Hermalin and Weisbach (2007) show more disclosure need not imply higher equity value (or performance). Increased information about the firm improves the ability of outsiders to monitor their managers. However, the benefits of better monitoring do not accrue entirely to shareholders: if managers have some bargaining power, then they will capture some of these benefits via greater compensation. If better governance is a substitute for the need to provide managers with monetary incentives in case of better transparency, then their effects might offset each other. More recently, Singh and Yerramilli (2009) even establish that an increase in transparency may either increase or decrease the sensitivity of stock price to earnings, and thus, may either strengthen or weaken managerial incentives, depending on the underlying level of uncertainty. Similarly, in an extension to Paul's (1992) baseline model, he demonstrates that a higher takeover threat can actually lower real efficiency and hence lower firm value. For a detailed review of the real effects of financial markets, see Bond, Edmans, and Goldstein (2012). Overall, the impact of an increase in transparency on equity prices (or performance) is thus ambiguous. Hence, one would not expect to find any reliable relation between governance, transparency, and performance. ${ }^{8}$

\footnotetext{
8 Note that this subsumes nonmonotonic relations, such as a U-shaped, inverted U-shape, or S-shape, which would not be detected by standard linear regression methods without appropriate conditioning (interaction) variables.
} 
More recently, Harris and Raviv (2010) consider how allocation of control rights between shareholders and their managers interacts with a company's information environment. They invalidate claims that shareholder control reduces equity value (or performance) for opaque firms (i.e., when outsiders do not have enough information when compared to insiders). Conversely, governance can improve firm performance for transparent firms. ${ }^{9}$ Consistent with this view, we stress that more transparent firms' synergies are easier to assess by outsiders and hence these firms are more attractive takeover targets. In fact, $\mathrm{Gu}$ (2012) documents that more transparent firms are more likely takeover targets and that this effect is statistically significant for good governance firms, but insignificant for bad governance firms. Martin and Shalev (2011) and McNichols and Stubben (2011) show that this is because acquiring firms can bid more effectively and expected synergies are larger for target firms that are more transparent. Similarly, Amel-Zadeh and Zhang (2011) and Marquardt and Zur (2011) find that low transparency (due to financial restatements or poor accrual quality) creates frictions in the market for corporate control and hence inhibits a more efficient allocation of resources via takeovers.

Consistent with this view, Duchin, Matsusaka, and Ozbas (2010) find that firm performance only increases for transparent firms when outsiders are added to the board. The interaction between governance and transparency is thus positive, because transparent firms are more likely targets, whereas opaque firms even might be protected from other channels that discipline their management. So, a good information environment can be crucial in facilitating takeovers and good governance only affects the performance of transparent firms. These arguments suggest that governance and transparency should be complements in terms of their influence on firm performance. Accordingly, the returns of transparent firms more reflect good governance than the ones of opaque firms.

Against the backdrop of the theoretical literature, it is an important question to evaluate which of these research directions are more in line with the data. This article provides an empirical answer as to whether and when governance and transparency tend to influence firm performance.

\footnotetext{
9 See also, Fishman and Hagerty (1989) for a similar argument that, by improving transparency, the firm makes it easier for outside investors to value the firm, which in turn reduces underinvestment and hence improves performance.
} 


\section{Data}

\subsection{SAMPLE SELECTION AND DEFINITION OF VARIABLES}

Our data sources are the Investor Responsibility Research Center (IRRC), which publishes detailed governance provisions for individual firms, the Center for Research in Security Prices (CRSP), and the Institutional Brokers' Estimates System (I/B/E/S). To be included in the sample, the firm must have a match in all of these data sets. For the 1990-2006 period, this leaves us with 2,959 companies.

The IRRC tracks 24 corporate governance-related provisions and the data are available for the years 1990, 1993, 1995, 1998, 2000, 2002, 2004, and 2006 during the sample period. For years, when data are not available, we use the observations from previous years. Based on these provisions, the Governance index ("G-index") is constructed as in GIM by adding one point to the index for the existence of each provision. The value of the G-index ranges from 0 to 24 to proxy for different degrees of corporate governance. In particular, firms with more provisions receive higher index values because they tend to have higher management power and weaker corporate governance. Firms with less provision are assigned lower index values because they tend to have stronger shareholder rights and hence better corporate governance. Following GIM, firms with a G-index of five or less are referred to as democratic firms and placed into the "Democracy Portfolio." Firms with a G-index of 14 or more are referred to as dictatorship firms and placed into the "Dictatorship Portfolio." As a robustness check, we also construct the Entrenchment index ("E-index") developed in Bebchuk, Cohen, and Ferrell (2009) using the IRRC data set. The E-index is based on 6 out of 24 corporate governance provisions and the construction method is similar to that of the G-index. Firms with an E-index value of zero fall into the "Democracy Portfolio" and firms with an E-index value of four or more are assigned to the "Dictatorship Portfolio." 10 As expected, the G-index and the E-index are highly correlated and the correlation between them is 0.71 over the period from 1990 to 2006.

Analysts' earning forecasts are used to gage a firm's accounting transparency. The data on analysts' earning forecasts are obtained from $\mathrm{I} / \mathrm{B} / \mathrm{E} / \mathrm{S}$. Based on the analysts' earnings forecast data, we construct three transparency proxies: forecast error, forecast dispersion, and revision volatility.

\footnotetext{
${ }_{10}$ Our results are similar when we follow Bebchuk, Cohen, and Ferrell (2009), who construct Democracy portfolios using E-index scores of 5 and 6. Our cutoff is in line with other recent studies (see, e.g., Giroud and Mueller, 2011). The Dictatorship portfolio then contains sufficiently many companies relative to the Democracy portfolio.
} 
In particular, forecast error is defined as the absolute value of the difference between the actual annual earnings per share (EPS) and the mean of analyst forecasts. Forecast dispersion is defined as the forecast standard deviation across all analysts following the same firm in the same year. Revision volatility is computed as the standard deviation of the changes over the fiscal year in the median forecast from the preceding month. These variables are all standard in the literature and are frequently used by researchers in accounting and finance. ${ }^{11}$ To make these measures of transparency comparable across firms, we deflate them by lagged stock price or by lagged total assets per share or by absolute value of forecast mean value. To ensure the reliability of these measures, we require that there are at least three different analysts providing forecasts for the firm during the year. All transparency proxies are constructed annually for each firm over the period from 1990 to 2006. To limit the influence of coding errors and outliers on our results, we remove observations for which forecast dispersion, forecast error, or revision volatility is larger than $10 \%$ of the share price at the beginning of the fiscal year (approximately $2 \%$ of the sample). ${ }^{12}$ As expected, the correlation coefficients between these variables are high. Using the data for all years, the correlation between forecast error and forecast dispersion is 0.47, the correlation between forecast error and revision volatility is 0.49 , and the correlation between forecast dispersion and revision volatility is 0.90 .

We also use data from other sources throughout the analysis. Monthly stock return data are obtained from CRSP. Data from Compustat and CDA/Spectrum (Thomson-Reuters Mutual Fund Holdings database) are used to construct control variables for further robustness checks. Monthly observations for the three risk factors come from Kenneth French's website. The momentum factor is constructed according to the procedure in Carhart (1997). The details will be described in later sections.

\subsection{EMPIRICAL RELATION BETWEEN TRANSPARENCY AND GOVERNANCE}

Governance and transparency are potentially chosen jointly by firms and hence the evidence in the paper may not be causal. We therefore begin our analysis by examining the empirical relation between the G-index and the transparency measures in a variety of ways. In essence, we find this relation

\footnotetext{
11 See, e.g., Givoly and Lakonishok (1979), Lang and Lundholm (1996), Thomas (2002), and Zhang (2006).

12 See, e.g., Easterwood and Nutt (1999), Lim (2001), Teoh and Wong (2002), and Giroud and Mueller (2011).
} 
is statistically insignificant, which is consistent with other studies (see, e.g., Larcker, Richardson, and Tuna, 2007). First, using all observations from 1990 to 2006, the correlation coefficients between G-index and forecast error, forecast dispersion, and revision volatility are $-0.003,-0.01$, and -0.01 , respectively. Put differently, they are economically small. Their $p$-values range from 0.51 to 0.86 , so none of the correlation coefficients are statistically significant. ${ }^{13}$

Second, we sort firms into three portfolios (i.e., lowest, medium, and highest tercile) according to their transparency measures in both Democracy and Dictatorship portfolios and find that the empirical distribution of the transparency proxies is very similar across the governance portfolios. For example, for the 1990-2006 period in Panel A of Table I, firms in the lowest forecast dispersion tercile of the Democracy portfolio have the same mean and median forecast dispersion as firms in the lowest forecast dispersion tercile of the Dictatorship portfolio. Observe that the mean and the median forecast dispersion are 0.001 in this tercile. Similar insights follow for the other two variables (i.e., forecast error and revision volatility) or for the sample period from 1990 to 1999 in Panel B.

Third, we investigate changes of a firm's information environment following changes in a firm's G-index and find no significant change of a firm's transparency following a change of its G-index in our sample during the 1990-99 period. A change of the G-index for a firm in year $t$ is computed as the difference between its G-index in year $t$ and $t-1$. Similarly, a change of the information environment for a firm in year $t$ is defined as the difference between the value of the transparency proxies in year $t$ and $t-1$. We then regress changes of a transparency proxy in year $t+1$ on changes of the G-index in year $t$ using four samples: (i) 1,518 observations that include all firms with nonzero G-index changes; (ii) 1,113 observations that only include firms with positive G-index changes; (iii) 405 observations that only include firms with negative G-index changes; and (iv) 215 observations that include only Democracy or Dictatorship firms with nonzero G-index changes. In these untabulated tests, we find for all transparency proxies in each of the four different samples a statistically insignificant relation between changes in governance and changes in transparency. For instance, using the 4th sample, the coefficient on the change of the G-index is -0.00092

13 Giroud and Mueller (2011) report almost no correlation between product market competition (i.e., HHI) and G-index. Yet, they find that competition and governance are substitutes in terms of firm performance. So, a substitutable or complementary effect on performance does not necessarily imply a negative or positive empirical relation between the variables of interest. 


\section{Table I. Summary statistics}

This table reports summary statistics on the empirical relation between the three transparency proxies and the G-index. The three transparency proxies are forecast dispersion, forecast error, and revision volatility. The definition of these variables is described in the data section. G-index is the governance index introduced in GIM and constructed using the 24 corporate provisions from the IRRC database. Firms are sorted into three subportfolios (i.e., lowest tercile, medium tercile, and highest tercile) based on the distribution of their transparency proxies in both Democracy and Dictatorship portfolios. Then, we compute the empirical distribution of transparency proxies between firms in the Democracy and the Dictatorship portfolios that are in the same tercile. Panel A presents statistics for the sample period from 1990 to 2006. Panel B presents statistics for the sample period from 1990 to 1999.

\begin{tabular}{|c|c|c|c|c|}
\hline & \multicolumn{2}{|c|}{ Democracy portfolio } & \multicolumn{2}{|c|}{ Dictatorship portfolio } \\
\hline & Mean & Median (range) & Mean & Median (range) \\
\hline \multicolumn{5}{|c|}{ Panel A: Distribution of transparency proxies in Democracy and Dictatorship portfolios (1990-2006) } \\
\hline \multicolumn{5}{|l|}{ Forecast dispersion } \\
\hline Lowest tercile & 0.001 & $0.001(0.0001,0.002)$ & 0.001 & $0.001(0.0001-0.002)$ \\
\hline Medium tercile & 0.003 & $0.003(0.002-0.006)$ & 0.003 & $0.003(0.002-0.004)$ \\
\hline Highest tercile & 0.01 & $0.01(0.006-0.04)$ & 0.01 & $0.01(0.004-0.04)$ \\
\hline \multicolumn{5}{|l|}{ Forecast error } \\
\hline Lowest tercile & 0.0005 & $0.0005(0.0001-0.01)$ & 0.0005 & $0.0006(0.0001-0.01)$ \\
\hline Medium tercile & 0.003 & $0.003(0.001-0.006)$ & 0.002 & $0.002(0.001-0.004)$ \\
\hline Highest tercile & 0.02 & $0.01(0.006-0.05)$ & 0.01 & $0.01(0.004-0.05)$ \\
\hline \multicolumn{5}{|l|}{ Revision volatility } \\
\hline Lowest tercile & 0.001 & $0.001(0.0001-0.002)$ & 0.001 & $0.001(0.0001-0.002)$ \\
\hline Medium tercile & 0.004 & $0.003(0.002-0.006)$ & 0.003 & $0.003(0.002-0.005)$ \\
\hline Highest tercile & 0.01 & $0.01(0.006-0.04)$ & 0.01 & $0.01(0.005-0.04)$ \\
\hline \multicolumn{5}{|c|}{ Panel B: Distribution of transparency proxies in Democracy and Dictatorship portfolios (1990-99 } \\
\hline \multicolumn{5}{|l|}{ Forecast dispersion } \\
\hline Lowest tercile & 0.001 & $0.001(0.0001-0.002)$ & 0.001 & $0.001(0.0001-0.002)$ \\
\hline Medium tercile & 0.003 & $0.003(0.002-0.005)$ & 0.003 & $0.003(0.002-0.004)$ \\
\hline Highest tercile & 0.01 & $0.01(0.005-0.04)$ & 0.01 & $0.01(0.004-0.04)$ \\
\hline \multicolumn{5}{|l|}{ Forecast error } \\
\hline Lowest tercile & 0.0004 & $0.0004(0.0001-0.001)$ & 0.0005 & $0.0005(0.0001-0.001)$ \\
\hline Medium tercile & 0.003 & $0.003(0.001-0.005)$ & 0.002 & $0.002(0.001-0.004)$ \\
\hline Highest tercile & 0.02 & $0.01(0.005-0.05)$ & 0.01 & $0.01(0.004-0.05)$ \\
\hline \multicolumn{5}{|l|}{ Revision volatility } \\
\hline Lowest tercile & 0.001 & $0.001(0.0001-0.002)$ & 0.001 & $0.001(0.0001-0.002)$ \\
\hline Medium tercile & 0.003 & $0.003(0.001-0.006)$ & 0.003 & $0.003(0.001-0.005)$ \\
\hline Highest tercile & 0.01 & $0.01(0.006-0.04)$ & 0.01 & $0.01(0.005-0.04)$ \\
\hline
\end{tabular}


$(t$-statistic $=0.54)$ for forecast error, it is $-0.00046(t$-statistic $=0.76)$ for forecast dispersion, and it is $-0.0015(t$-statistic $=0.76)$ for revision volatility. ${ }^{14}$

\section{Results}

\subsection{TRADING STRATEGIES}

In this section, we study the performance of trading strategies that rely on information contained in transparency proxies and in the corporate governance provisions. Recall that, GIM identify a 9\% per year disparity between the return of the Democracy portfolio and that of the Dictatorship portfolio over the period from 1990 to 1999 . They employ Carhart's four-factor model to account for the style or risk differences of the two portfolios. GIM use the estimated intercept coefficient as the abnormal return to measure the effects of good governance on equity returns.

We also use Carhart's four-factor model to identify the abnormal return (i.e., the intercept $\alpha$ of a regression model), where the momentum factor is constructed according to the procedure in Carhart (1997). In particular, we estimate the following model:

$$
R_{t}=\alpha+\beta_{1} \times \mathrm{RMRF}_{t}+\beta_{2} \times \mathrm{SMB}_{t}+\beta_{3} \times \mathrm{HML}_{t}+\beta_{4} \times \mathrm{UMD}_{t}+\epsilon_{t},
$$

where $R_{t}$ is the excess monthly return of a common stock or a portfolio, $\mathrm{RMRF}_{t}$ is the value-weighted market return minus the risk-free rate in month $t, \mathrm{SMB}_{t}$ is the month $t$ size factor, $\mathrm{HML}_{t}$ is the book-to-market factor in month $t$, and $\mathrm{UMD}_{t}$ is the month $t$ Carhart momentum factor. $\mathrm{RMRF}_{t}, \mathrm{SMB}_{t}$, and $\mathrm{HML}_{t}$ factors are downloaded from Kenneth French's website and $\mathrm{UMD}_{t}$ factor is constructed according to Carhart (1997).

Our article examines the joint effect of corporate governance and firm transparency on returns. Analogous to GIM and others, we construct a hedge portfolio that takes a long position in the Democracy portfolio and a short position in the Dictatorship portfolio. Similar to the procedure of Giroud and Mueller (2011) for industry competition, we split both Democracy portfolio and Dictatorship portfolio into three terciles based on the three transparency proxies. ${ }^{15}$ This leaves us with $2 \times 3=6$ equal-sized

\footnotetext{
14 The unreported results for samples (1-3) are available from the authors upon request.

15 In unreported results, we have experimented with the sample median of the transparency proxies to create two (instead of three) groups and quartile portfolios to create four (instead of three) groups. Both methods lead to similar findings.
} 
portfolios for each of the three transparency proxies. ${ }^{16}$ Therefore, we have in total $3 \times 3=9$ hedge portfolios with a long position in a Democracy portfolio and a short position in a Dictatorship portfolio.

To test the effect of corporate governance using the tercile portfolios based on transparency proxies, we must make sure that the distributions of the analyst variables in the same tercile are sufficiently close to each other in the Democracy and the Dictatorship portfolio. This requirement is satisfied in our sample, given the summary statistics in Table I discussed in previous subsection. In each tercile, we estimate the four-factor model and $R_{t}$ is the monthly return differences between the Democracy and Dictatorship portfolios. The reported value-weighted monthly return is calculated by weighting the return of each individual stock in the portfolio by its market capitalization at the end of the previous month and equal-weighted monthly return is the average of the return of each individual stock in the portfolio.

The IRRC updates corporate provisions in August 1990, June 1993, June 1995, and January 1998. We assign new values of G-index to firms 1 month after the IRRC updates. So the Democracy and Dictatorship portfolios are reset in September 1990, July 1993, July 1995, and February 1998. The transparency measures are calculated annually using yearly $\mathrm{I} / \mathrm{B} / \mathrm{E} / \mathrm{S}$ data. To avoid the look-ahead bias, we rebalance the hedge portfolio each July using previous year's value of transparency proxies. Our main analysis focuses on the period from September 1990 to December 1999, which is the sample period used in GIM and others. In robustness checks, we also extend the sample period to 2011 .

\subsection{BASELINE RESULTS}

In Table II, we report GIM's original results and our replication of their results. The 1st row in Panel A is the result in GIM's (2003) paper. It shows that the value-weighted Democracy-Dictatorship hedge portfolio earns a monthly abnormal return of $0.71 \%$, which is statistically significant at the $1 \%$ level. Row (2) reports our replication of their result. Observe that our estimate of $\alpha$ equals $0.67 \%$, with significance at the $1 \%$ level. The alpha and factor loadings are very similar, but not identical. ${ }^{17}$ In Row (3), we perform the same estimation using our restricted sample and obtain a reliably positive

\footnotetext{
16 We have verified that our results are invariant to the order in which we construct portfolios. Recall that the correlation between the transparency proxies and the G-index is essentially zero and insignificant.

17 For example, Core, Guay, and Rusticus (2006) and Giroud and Mueller (2011) report slightly different estimates for their replications, which are more in line with our replication.
} 
Table II. Trading strategies: full sample

This table reports the alphas for regressions of monthly excess returns to a hedge portfolio that takes a long position in Democracy firms and a short position in Dictatorship firms on an intercept $(\alpha)$, the market factor (RMRF), the size factor (SMB), the book-to-market factor (HML), and the momentum factor (UMD). RMRF, SMB, and HML factors are taken from Kenneth French's website. UMD factor is constructed according to Carhart (1997). G-index is the governance index introduced in GIM and constructed using the 24 corporate provisions from the IRRC database. Firms with a G-index of five or less are referred to as democratic firms and firms with a G-index of 14 or more are referred to as dictatorship firms. Panel A represents the value-weighted results, for which the monthly returns are value-weighted by the market capitalization at the end of previous month. Panel B reports the equal-weighted results. In each panel, the original results from GIM, the replication results, and the results using our sample are presented. The sample period ranges from September 1990 through December 1999. $t$-statistics are reported in parentheses under the estimation coefficient. The significance levels $1 \%, 5 \%$, and $10 \%$ are denoted by $* * *, * *$, and $*$, respectively.

\begin{tabular}{lccccc}
\hline & $\alpha$ & RMRF & SMB & HML & UMD \\
\hline Panel A: Value-weighted Democracy-Dictatorship hedge & portfolios & & \\
\hline GIM (2003) & $0.71^{* * *}$ & -0.04 & -0.22 & -0.55 & -0.01 \\
& $(2.73)$ & $(0.57)$ & $(2.44)$ & $(5.50)$ & $(0.14)$ \\
Replication & $0.67 * *$ & -0.04 & -0.24 & -0.54 & 0.02 \\
& $(2.67)$ & $(0.57)$ & $(2.71)$ & $(5.27)$ & $(0.26)$ \\
Our sample & $0.68^{* *}$ & -0.05 & -0.24 & -0.56 & 0.03 \\
& $(2.57)$ & $(0.60)$ & $(2.64)$ & $(5.17)$ & $(0.47)$ \\
\hline \multirow{2}{*}{ Panel B: Equal-weighted Democracy-Dictatorship hedge } & portfolios & & \\
\hline \multirow{2}{*}{ GIM (2001) } & $0.45^{* *}$ & -0.00 & 0.23 & -0.38 & -0.16 \\
& $(2.06)$ & $(0.01)$ & $(3.02)$ & $(4.30)$ & $(2.79)$ \\
Replication & $0.47 * *$ & -0.03 & 0.23 & -0.38 & -0.16 \\
& $(2.16)$ & $(0.50)$ & $(3.03)$ & $(4.28)$ & $(3.10)$ \\
Our sample & $0.35^{*}$ & -0.01 & 0.19 & -0.47 & -0.11 \\
& $(1.77)$ & $(0.19)$ & $(2.73)$ & $(5.80)$ & $(2.27)$ \\
\hline
\end{tabular}

$\alpha$ of $0.68 \%(t$-statistic $=2.57)$ as a base case. The coefficients for the risk factors are similar to those reported in GIM, who only document results for value-weighted portfolios. However, for comparison to our results based on equal-weighted portfolios, we report in the 2 nd row of Panel B a replication of GIM's (2001) equal-weighted results, which are presented in the 1st row. As revealed by the table, the alpha and factor loadings are again very similar in terms of economic magnitude and statistical significance. Finally, the 3rd row tabulates the baseline results for our restricted sample.

Table III presents our main results. We divide both Democracy and Dictatorship portfolios into three equal-sized (tercile) portfolios based on the three transparency proxies: forecast dispersion, forecast error, and 


\section{Table III. Trading strategies: transparency proxies}

This table reports abnormal returns for equal- and value-weighted Democracy-Dictatorship hedge portfolios using the Carhart four-factor model. Both Democracy and Dictatorship portfolios are divided into three terciles based on the three transparency proxies deflated by either lagged share price or lagged assets per share or absolute value of forecast mean: forecast dispersion, forecast error, and revision volatility. Then we form a DemocracyDictatorship hedge portfolio for each transparency tercile every month and regress the monthly excess returns to each hedge portfolio on the market factor (RMRF), the size factor (SMB), the book-to-market factor (HML), and the momentum factor (UMD). The estimated intercept $\alpha$ is interpreted as the abnormal return of the trading strategy. Forecast error is defined as the absolute value of the difference between the actual annual EPS and the mean of analyst forecasts. Forecast dispersion is defined as the forecast standard deviation across all analysts following the same firm in the same year. Revision volatility is computed as the standard deviation of the changes over the fiscal year in the median forecast from the preceding month. Panel A reports the $\alpha$ when transparency proxies are scaled by lagged share price. Panels $\mathrm{B}$ and $\mathrm{C}$ show the results when transparency proxies are scaled by lagged assets per share and absolute value of forecast mean, respectively. The last two columns show the value-weighted abnormal returns to the Democracy (Long) and Dictatorship (Short) portfolios for the high transparency groups (i.e., lowest terciles). The sample period is from September 1990 to December 1999. $t$-statistics are reported in parentheses under the estimation coefficient. The significance levels $1 \%, 5 \%$, and $10 \%$ are denoted by $* * *, * *$, and $*$, respectively.

\begin{tabular}{|c|c|c|c|c|c|c|c|}
\hline \multicolumn{3}{|c|}{ Equal-weighted hedge portfolio } & \multicolumn{5}{|c|}{ Value-weighted hedge portfolio } \\
\hline $\begin{array}{l}\text { Lowest } \\
\text { tercile }\end{array}$ & $\begin{array}{l}\text { Medium } \\
\text { tercile }\end{array}$ & $\begin{array}{l}\text { Highest } \\
\text { tercile }\end{array}$ & $\begin{array}{l}\text { Lowest } \\
\text { tercile }\end{array}$ & $\begin{array}{l}\text { Medium } \\
\text { tercile }\end{array}$ & $\begin{array}{l}\text { Highest } \\
\text { tercile }\end{array}$ & $\begin{array}{l}\text { Long } \\
\text { leg }\end{array}$ & $\begin{array}{l}\text { Short } \\
\text { leg }\end{array}$ \\
\hline
\end{tabular}

Panel A: Transparency proxies scaled by lagged price

\begin{tabular}{lcccccccc}
\hline Forecast dispersion & $0.73^{* *}$ & 0.40 & 0.05 & $0.99^{* * *}$ & 0.40 & -0.21 & $0.81^{* * *}$ & -0.18 \\
& $(2.41)$ & $(1.31)$ & $(0.18)$ & $(3.00)$ & $(0.87)$ & $(0.50)$ & $(3.92)$ & $(0.79)$ \\
Forecast error & $0.80^{* * *}$ & 0.24 & 0.01 & $0.97 * * *$ & 0.09 & 0.06 & $0.76^{* * *}$ & -0.21 \\
& $(2.88)$ & $(0.86)$ & $(0.01)$ & $(2.99)$ & $(0.22)$ & $(0.15)$ & $(3.88)$ & $(0.81)$ \\
Revision volatility & $0.52^{* *}$ & 0.27 & 0.13 & $0.73^{* *}$ & 0.05 & 0.76 & $0.57^{* * *}$ & -0.17 \\
& $(2.02)$ & $(1.11)$ & $(0.41)$ & $(2.04)$ & $(0.14)$ & $(1.57)$ & $(2.90)$ & $(0.59)$ \\
\hline
\end{tabular}

Panel B: Transparency proxies scaled by lagged assets

\begin{tabular}{lcccccccc}
\hline Forecast dispersion & $0.61^{* * *}$ & 0.10 & 0.34 & $0.79^{* *}$ & 0.36 & 0.29 & $0.50^{* *}$ & -0.29 \\
& $(2.59)$ & $(0.34)$ & $(0.65)$ & $(2.32)$ & $(0.81)$ & $(0.40)$ & $(2.41)$ & $(1.19)$ \\
Forecast error & $0.56^{* *}$ & 0.37 & 0.16 & $0.80^{* *}$ & 0.87 & 0.08 & $0.48^{* *}$ & -0.31 \\
& $(2.24)$ & $(1.22)$ & $(0.36)$ & $(2.31)$ & $(1.85)$ & $(0.13)$ & $(2.43)$ & $(1.26)$ \\
Revision volatility & $0.68^{* * *}$ & 0.20 & 0.14 & $0.59^{*}$ & 0.62 & 0.83 & $0.43^{*}$ & -0.16 \\
& $(2.61)$ & $(0.54)$ & $(0.36)$ & $(1.72)$ & $(1.47)$ & $(0.21)$ & $(1.94)$ & $(0.61)$ \\
\hline
\end{tabular}

Panel C: Transparency proxies scaled by forecast mean

\begin{tabular}{lcccccccc}
\hline Forecast dispersion & $0.51^{*}$ & 0.40 & 0.24 & $0.92^{* * *}$ & 0.46 & 0.13 & $0.66^{* * *}$ & -0.17 \\
& $(1.75)$ & $(1.39)$ & $(0.74)$ & $(2.67)$ & $(1.15)$ & $(0.24)$ & $(3.22)$ & $(0.82)$ \\
Forecast error & $0.44^{*}$ & 0.48 & 0.14 & $0.83^{* *}$ & $0.67^{*}$ & -0.04 & $0.45^{* *}$ & -0.30 \\
& $(1.70)$ & $(1.56)$ & $(0.44)$ & $(2.55)$ & $(1.93)$ & $(0.08)$ & $(2.15)$ & $(1.16)$ \\
Revision volatility & $0.48^{*}$ & 0.24 & 0.43 & $0.74^{* *}$ & 0.14 & 0.72 & $0.53^{* * *}$ & -0.25 \\
& $(1.73)$ & $(0.72)$ & $(1.22)$ & $(2.34)$ & $(0.27)$ & $(1.41)$ & $(2.77)$ & $(1.24)$ \\
\hline
\end{tabular}


revision volatility. This leaves us with three Democracy-Dictatorship hedge portfolios. We obtain the abnormal return $\alpha$ by running a time-series regression of the monthly excess returns of each hedge portfolio on the market factor (RMRF), the size factor (SMB), the book-to-market factor (HML), and the momentum factor (UMD). Panel A reports the abnormal returns of the trading strategy, when transparency proxies are scaled by lagged share price. We provide results for both equal- and value-weighted portfolios. In the 1st row of Panel A, forecast dispersion is used to construct the terciles. The estimated abnormal return is reliably positive for the hedge portfolio in the lowest tercile, whereas the alphas in the medium and the highest tercile are much smaller and insignificant or less significant. Notably, this monotonically declining pattern for alpha prevails for both equal- and value-weighted portfolios. More specifically, for the equal-weighted portfolios, the alpha is $0.73 \%$ and significant at the $5 \%$ level $(t$-statistic $=2.41)$ in the lowest tercile, it is $0.40 \%$ and insignificant $(t$-statistic $=1.31)$ in the medium tercile, and it is $0.05 \%$ without significance $(t$-statistic $=0.18)$ in the highest tercile. The difference between the alphas in the lowest and the highest terciles equals $0.68 \%$, which is significant at the $10 \%$ level. For the value-weighted portfolios, the alpha is $0.99 \%$ with a significance at $1 \%$ level in the lowest tercile $(t$-statistic $=3.00)$, whereas it is economically smaller and statistically insignificant in the medium and the highest terciles. The difference between the alphas in the lowest and the highest terciles equals $1.20 \%$, which is significant at the $5 \%$ level. Finally, notice that the economic magnitude of the abnormal return in the lowest tercile exceeds the one in Table II for the full sample.

In the 2 nd and the 3 rd row of Panel A, we report the abnormal returns of the trading strategy when analyst forecast error and revision volatility are employed, respectively. Interestingly, similar abnormal return patterns obtain when replacing forecast dispersion by these variables. That is, we always estimate a positive and significant abnormal return in the lowest tercile, and we get small and insignificant abnormal returns for most of the estimations in other terciles. For example, for the equal-weighted portfolios formed based on forecast error and corporate governance, the abnormal return equals $0.80 \%$ with $1 \%$ significance $(t$-statistic $=2.88)$ in the lowest tercile and $0.01 \%$ with no significance $(t$-statistic $=0.01)$ in the highest tercile. Using revision volatility, the alpha is $0.52 \%$ and significant ( $t$ statistic $=2.02)$ in the lowest tercile of the equal-weighted hedge portfolio, whereas it is $0.13 \%$ and insignificant $(t$-statistic $=0.41)$ in the highest tercile.

The results show that the Democracy-Dictatorship trading strategy is more effective when it is restricted to firms for which analysts have less difficulty in making forecasts. Since firms' transparency facilitate actual 
takeovers, the positive effect of lack of anti-takeover and shareholder rights provisions (good governance) is strengthened. GIM's sample draws on firms with various levels of transparency. Clearly, their estimates of abnormal returns are an average effect that describes the relation between governance and returns for both opaque and transparent firms. Recall that, for example, the equal-weighted abnormal return is $0.45 \%$ in GIM's (2001) study. However, the abnormal return in our lowest terciles is much larger, ranging from $0.52 \%$ to $0.80 \%$, because these lowest terciles restrict the trading strategy to include only the more transparent firms from the full sample.

Panel B of Table III contains the estimation results for the same tests as in Panel A except that the transparency proxies are scaled by lagged total assets per share instead of lagged stock price. Notably, the transparency-related patterns of abnormal returns are qualitatively and quantitatively very similar to the ones in the previous table. Observe, for example, that the value-weighted alpha of the trading strategy based on forecast dispersion is $0.79 \%$ and significant $(t$-statistic $=2.32)$ in the lowest tercile, it is $0.36 \%$ and insignificant $(t$-statistic $=0.81)$ in the medium tercile, and it is $0.29 \%$ and insignificant $(t$-statistic $=0.40)$ in the highest tercile. Thus, irrespective of the deflator for transparency proxies, we find a monotonically declining pattern in abnormal returns when forecast error, forecast dispersion, or revision volatility rises (i.e., transparency deteriorates).

Panel C of Table III reports results when transparency measures are scaled by absolute value of forecast mean value instead of lagged stock price or lagged assets per share. ${ }^{18}$ Again, we obtain similar patterns for abnormal return alpha. For instance, the value-weighted alpha of the trading strategy based on forecast error is $0.83 \%$ and significant $(t$-statistic $=2.55)$ in the lowest tercile, it is $0.67 \%$ and less significant $(t$-statistic $=1.93)$ in the medium tercile, and it is $-0.04 \%$ and insignificant $(t$-statistic $=0.08)$ in the highest tercile.

To see which side of the hedge portfolio contributes to its abnormal returns in the lowest tercile, we perform return decomposition analysis. The last two columns of Table III report the value-weighted four-factor $\alpha$ of the Democracy and Dictatorship portfolios in the high transparency groups (i.e., lowest terciles). Observe that the long leg of the hedge portfolio is associated with significantly positive abnormal returns, whereas the $\alpha$ of the short leg is negative, economically small, and not statistically significant. For example, in Panel A, when the transparency proxy is forecast dispersion,

$\overline{18}$ We have also verified in unreported estimations that deleting all observations with negative forecast mean does not affect our results. 
the long- and short-side $\alpha$ 's are, respectively, $0.81 \%(t$-statistic $=3.92)$ and $-0.18 \%$ ( $t$-statistic $=0.79)$, resulting in a $0.99 \%$ abnormal return to the hedge protfolio. Furthermore, this pattern holds in all cases across all three panels. ${ }^{19}$ Overall, the result of this analysis indicates that the abnormal returns to the hedge portfolio largely comes from the long side and good governance firms are associated with positive and significant abnormal returns among transparent firms.

\subsection{TIME-SERIES AVERAGE OF TRANSPARENCY PROXIES}

We also perform our baseline tests with time-series averages of forecast dispersion, forecast error, and revision volatility, which are largely outside of managers' discretion and hence more permanent firm characteristics. These time-series averages are time-invariant and hence more exogenous. Hence, the hedge portfolios are not affected by potentially strategic information disclosure or time-varying information arrival. Table IV collects the results when we use time-invariant sample averages of transparency proxies for three different deflators. ${ }^{20}$ We report abnormal returns for both equal- and value-weighted hedge portfolios using the Carhart four-factor model. The prevailing pattern in the table reinforces our earlier findings. In all tests, we find large and significant abnormal returns in the lowest tercile that contains transparent firms, and small and insignificant abnormal returns for the highest tercile that contains opaque firms. Perhaps surprisingly, when we remove the time-series variation of the transparency measures, the economic and the statistical significance of the abnormal returns in the high transparency terciles remain largely unchanged.

\subsection{PRINCIPAL COMPONENT OF TRANSPARENCY PROXIES}

So far, we use the three transparency proxies individually to proxy for firm transparency level. Although the three variables are correlated with each other, they still convey different characteristics of analyst earnings forecasts and thus contain different information about the firm's information

\footnotetext{
19 We also perform the return decomposition analysis to the equal-weighted portfolios and obtain similar results. For instance, in the case of forecast dispersion scaled by lagged price, the long- and short-side $\alpha$ is $0.70 \%(t$-statistic $=3.71)$ and $-0.04 \%(t$-statistic $=0.15)$, respectively. We do not tabulate the equal-weighted return decomposition results in Table III (to save space), but they are available from the authors upon request.

20 In untabulated results, we also use the sample averages of transparency proxies over the period of 1982-90 as a time-invariant measure of a firm's transparency level and obtain similar abnormal return patterns.
} 
Table IV. Trading strategies: time-series average of transparency proxies

This table reports abnormal returns for equal- and value-weighted Democracy-Dictatorship hedge portfolios using the Carhart four-factor model. Both Democracy and Dictatorship portfolios are divided into three terciles based on the three transparency proxies' time-series averages: forecast dispersion, forecast error, and revision volatility. This leaves us with three Democracy-Dictatorship hedge portfolios every month. We then regress the monthly excess returns to each hedge portfolio on the market factor (RMRF), the size factor (SMB), the book-to-market factor (HML), and the momentum factor (UMD). The estimated intercept $\alpha$ is interpreted as the abnormal return of the trading strategy. Panel A reports the $\alpha$ when transparency proxies are scaled by lagged share price. Panels B and C show the results when transparency proxies are scaled by lagged assets per share and absolute value of forecast mean, respectively. The sample period is from September 1990 to December 1999. $t$-statistics are reported in parentheses under the estimation coefficient. The significance levels $1 \%$, $5 \%$, and $10 \%$ are denoted by $* * *, * *$, and $*$, respectively.

\begin{tabular}{|c|c|c|c|c|c|c|}
\hline & \multicolumn{3}{|c|}{ Equal-weighted hedge portfolio } & \multicolumn{3}{|c|}{ Value-weighted hedge portfolio } \\
\hline & $\begin{array}{l}\text { Lowest } \\
\text { tercile }\end{array}$ & $\begin{array}{l}\text { Medium } \\
\text { tercile }\end{array}$ & $\begin{array}{l}\text { Highest } \\
\text { tercile }\end{array}$ & $\begin{array}{l}\text { Lowest } \\
\text { tercile }\end{array}$ & $\begin{array}{l}\text { Medium } \\
\text { tercile }\end{array}$ & $\begin{array}{l}\text { Highest } \\
\text { tercile }\end{array}$ \\
\hline \multicolumn{7}{|c|}{ Panel A: Transparency proxies scaled by lagged price } \\
\hline Forecast dispersion & $\begin{array}{l}0.71 * * \\
(2.44)\end{array}$ & $\begin{array}{c}0.41 \\
(1.41)\end{array}$ & $\begin{array}{c}0.03 \\
(0.11)\end{array}$ & $\begin{array}{l}0.86^{* *} \\
(2.47)\end{array}$ & $\begin{array}{c}0.16 \\
(0.42)\end{array}$ & $\begin{array}{l}-0.16 \\
(0.39)\end{array}$ \\
\hline Forecast error & $\begin{array}{l}0.75^{* * * *} \\
(2.90)\end{array}$ & $\begin{array}{c}0.16 \\
(0.50)\end{array}$ & $\begin{array}{c}0.13 \\
(0.42)\end{array}$ & $\begin{array}{l}0.78^{* * *} \\
(2.30)\end{array}$ & $\begin{array}{c}0.26 \\
(0.65)\end{array}$ & $\begin{array}{c}0.18 \\
(0.44)\end{array}$ \\
\hline Revision volatility & $\begin{array}{l}0.60 * * \\
(2.09)\end{array}$ & $\begin{array}{c}0.53 \\
(1.67)\end{array}$ & $\begin{array}{c}-0.09 \\
(0.28)\end{array}$ & $\begin{array}{l}0.69^{*} \\
(1.86)\end{array}$ & $\begin{array}{c}0.09 \\
(0.27)\end{array}$ & $\begin{array}{c}0.70 \\
(1.35)\end{array}$ \\
\hline \multicolumn{7}{|c|}{ Panel B: Transparency proxies scaled by lagged assets } \\
\hline Forecast dispersion & $\begin{array}{l}0.57^{* *} \\
(2.51)\end{array}$ & $\begin{array}{c}0.56 \\
(1.28)\end{array}$ & $\begin{array}{c}0.23 \\
(0.58)\end{array}$ & $\begin{array}{l}0.76^{* * *} \\
(2.26)\end{array}$ & $\begin{array}{c}0.44 \\
(0.95)\end{array}$ & $\begin{array}{c}0.43 \\
(0.73)\end{array}$ \\
\hline Forecast error & $\begin{array}{l}0.63 * * * \\
(2.75)\end{array}$ & $\begin{array}{c}0.41 \\
(0.88)\end{array}$ & $\begin{array}{c}0.28 \\
(0.67)\end{array}$ & $\begin{array}{l}0.75^{* *} \\
(2.22)\end{array}$ & $\begin{array}{c}0.56 \\
(1.26)\end{array}$ & $\begin{array}{c}0.75 \\
(1.29)\end{array}$ \\
\hline Revision volatility & $\begin{array}{l}0.67^{* *} \\
(2.13)\end{array}$ & $\begin{array}{c}0.45 \\
(1.38)\end{array}$ & $\begin{array}{c}0.22 \\
(0.64)\end{array}$ & $\begin{array}{l}0.28 \\
(0.65)\end{array}$ & $\begin{array}{c}0.83^{*} \\
(1.92)\end{array}$ & $\begin{array}{c}0.46 \\
(0.92)\end{array}$ \\
\hline \multicolumn{7}{|c|}{ Panel C: Transparency proxies scaled by forecast mean } \\
\hline Forecast dispersion & $\begin{array}{c}0.45^{*} \\
(1.88)\end{array}$ & $\begin{array}{c}0.35 \\
(1.20)\end{array}$ & $\begin{array}{c}0.24 \\
(0.76)\end{array}$ & $\begin{array}{l}0.83 * * * \\
(2.58)\end{array}$ & $\begin{array}{c}0.03 \\
(0.08)\end{array}$ & $\begin{array}{c}0.31 \\
(0.54)\end{array}$ \\
\hline Forecast error & $\begin{array}{l}0.56^{* *} \\
(2.52)\end{array}$ & $\begin{array}{c}0.30 \\
(0.83)\end{array}$ & $\begin{array}{c}0.18 \\
(0.54)\end{array}$ & $\begin{array}{l}0.74 * * \\
(2.24)\end{array}$ & $\begin{array}{c}0.30 \\
(0.66)\end{array}$ & $\begin{array}{c}0.22 \\
(0.37)\end{array}$ \\
\hline Revision volatility & $\begin{array}{l}0.59^{* * *} \\
(2.01)\end{array}$ & $\begin{array}{c}0.47 \\
(1.67)\end{array}$ & $\begin{array}{c}0.01 \\
(0.03)\end{array}$ & $\begin{array}{l}0.93^{* * * *} \\
(2.60)\end{array}$ & $\begin{array}{c}0.24 \\
(0.49)\end{array}$ & $\begin{array}{c}0.18 \\
(0.31)\end{array}$ \\
\hline
\end{tabular}

environment. In this section, we combine all the information contained in forecast error, forecast dispersion, and revision volatility by constructing their 1st principal component. Principal component analysis is appropriate to reduce several observed variables into a smaller number of principal 
Table $V$. Trading strategies: principal component of transparency proxies

This table reports abnormal returns for equal- and value-weighted Democracy-Dictatorship hedge portfolios using the Carhart four-factor model. We first divide both Democracy and Dictatorship portfolios into three terciles based on the first principal component of forecast dispersion, forecast error, and revision volatility. This leaves us with three DemocracyDictatorship hedge portfolios every month. We then regress the monthly excess returns to each hedge portfolio on the market factor (RMRF), the size factor (SMB), the book-to-market factor (HML), and the momentum factor (UMD). The estimated intercept $\alpha$ is interpreted as the abnormal return of the trading strategy. Panel A reports the $\alpha$ when transparency proxies are scaled by lagged share price. Panels B and C show the results when transparency proxies are scaled by lagged assets per share and absolute value of forecast mean, respectively. The sample period is from September 1990 to December 1999. $t$-statistics are reported in parentheses under the estimation coefficient. The significance levels $1 \%$, $5 \%$, and $10 \%$ are denoted by $* * *, * *$, and $*$, respectively.

\begin{tabular}{|c|c|c|c|c|c|c|}
\hline & \multicolumn{3}{|c|}{ Equal-weighted hedge portfolio } & \multicolumn{3}{|c|}{ Value-weighted hedge portfolio } \\
\hline & $\begin{array}{l}\text { Lowest } \\
\text { tercile }\end{array}$ & $\begin{array}{l}\text { Medium } \\
\text { tercile }\end{array}$ & $\begin{array}{l}\text { Highest } \\
\text { tercile }\end{array}$ & $\begin{array}{l}\text { Lowest } \\
\text { tercile }\end{array}$ & $\begin{array}{l}\text { Medium } \\
\text { tercile }\end{array}$ & $\begin{array}{l}\text { Highest } \\
\text { tercile }\end{array}$ \\
\hline \multicolumn{7}{|c|}{ Panel A: Transparency proxies scaled by lagged share price } \\
\hline$\alpha$ & $\begin{array}{l}1.28^{* * *} \\
(3.50)\end{array}$ & $\begin{array}{l}-0.22 \\
(0.69)\end{array}$ & $\begin{array}{c}0.04 \\
(0.11)\end{array}$ & $\begin{array}{l}1.37^{* * *} \\
(3.52)\end{array}$ & $\begin{array}{c}0.15 \\
(0.31)\end{array}$ & $\begin{array}{c}0.04 \\
(0.09)\end{array}$ \\
\hline \multicolumn{7}{|c|}{ Panel B: Transparency proxies scaled by lagged assets } \\
\hline$\alpha$ & $\begin{array}{l}0.76^{* *} \\
(2.47)\end{array}$ & $\begin{array}{c}0.15 \\
(0.41)\end{array}$ & $\begin{array}{c}0.53 \\
(0.96)\end{array}$ & $\begin{array}{l}1.10^{* *} \\
(2.45)\end{array}$ & $\begin{array}{c}0.88^{*} \\
(1.88)\end{array}$ & $\begin{array}{c}-0.20 \\
(0.29)\end{array}$ \\
\hline \multicolumn{7}{|c|}{ Panel C: Transparency proxies scaled by forecast mean } \\
\hline$\alpha$ & $\begin{array}{c}0.53^{*} \\
(1.90)\end{array}$ & $\begin{array}{c}0.28 \\
(0.92)\end{array}$ & $\begin{array}{c}0.35 \\
(0.94)\end{array}$ & $\begin{array}{l}0.89^{* * * *} \\
(2.95)\end{array}$ & $\begin{array}{c}0.54 \\
(1.29)\end{array}$ & $\begin{array}{c}0.03 \\
(0.06)\end{array}$ \\
\hline
\end{tabular}

components that account for most of the variation in the observed variables. That is, we replace the transparency measures with their 1st principal component and re-estimate the four-factor model in Equation (1). The estimation results are presented in Table $\mathrm{V}$ for equal- and value-weighted Democracy-Dictatorship hedge portfolios.

Panel A of Table V reports the alphas for the trading strategy when transparency proxies are scaled by lagged share price. For the equal-weighted hedge portfolios, the alpha is $1.28 \%$ and significant $(t$-statistic $=3.50)$ in the lowest tercile, it is $-0.22 \%$ and insignificant $(t$-statistic $=0.69)$ in the medium tercile, and it is $0.04 \%$ and insignificant $(t$-statistic $=0.11)$ in the highest tercile. For the value-weighted hedge portfolios, the alpha is $1.37 \%$ and significant $(t$-statistic $=3.52)$ in the lowest tercile, it is $0.15 \%$ and 
insignificant $(t$-statistic $=0.31)$ in the medium tercile, and it is $0.04 \%$ and insignificant $(t$-statistic $=0.09)$ in the highest tercile. The relation between abnormal returns and firm transparency we obtain in this table again strongly supports our previous findings. In addition, notice that combining the individual information from the three variables yields economically larger estimates for alpha. More specifically, Panel A shows that the value-weighted hedge portfolio - provided it only includes more transparent firms as defined by the first principal component of forecast error, forecast dispersion, and revision volatility - earns a monthly alpha of $1.37 \%$ ( $t$-statistic $=3.52)$, which is almost twice as large as the alpha estimate of $0.71 \%$ reported in GIM.

In Panels $\mathrm{B}$ and $\mathrm{C}$, we employ the transparency proxies' 1st principal component scaled by lagged total assets per share and absolute value of forecast mean, respectively, and re-estimate the four-factor model in Equation (1). The test results are similar to the ones reported in Panel A.

Overall, Tables III-V provide novel and strong support for the hypothesis that more transparent firms benefit relatively more from good corporate governance, whereas more opaque firms benefit relatively less from good governance. Due to transparent firms, there is more precise information available to investors, it is less difficult for outsiders to assess synergies, which facilitates actual takeovers (e.g., Amel-Zadeh and Zhang, 2011; Marquardt and Zur, 2011; Martin and Shalev, 2011; McNichols and Stubben, 2011). This strengthens the effect of good governance. Thus, the abnormal returns of the trading strategy focusing on transparent firms are positive and significant. On the other hand, there is less precise information available for opaque firms, which we proxy by the noise contained in analyst earnings forecasts. As a result, it is more difficult, if not impossible, for outsiders to assess synergies. Thus, opaque firms might not be taken over even if they lack anti-takeover and shareholder rights provisions. So the abnormal returns of the trading strategy focusing on opaque firms are small and insignificant.

Consistent with our main result, we find that target firms are, on average, relatively more transparent. We compare the average forecast dispersion, forecast error, or revision volatility of target firms to all firms in the sample over the 1990-2006 period. For example, the average forecast dispersion is 0.043 for the subsample of target firms, whereas it is 0.197 for the sample of all firms, and the difference between the two is statistically significant at the $1 \%$ level. Moreover, Gu (2012) employs an empirical logit model including transparency as additional predicting variable. She documents that firm transparency has a significantly positive association with takeover likelihood. Using this specification, we find in untabulated results that only 
good governance firms, which are transparent, are more likely takeover targets. Taken together, these results support the view that transparency facilitates takeovers and hence increases takeover vulnerability.

\section{Robustness}

\subsection{VARIANTS OF THE TRADING STRATEGY}

Table VI presents the results for the 1st set of robustness checks. In Panel A, accruals quality is used to measure firm transparency instead of analyst variables. Following McNichols (2002), ${ }^{21}$ accruals quality is constructed as the standard deviation of the residuals of the following estimation model:

$$
\Delta W C_{t}=b_{0}+b_{1} C F O_{t-1}+b_{2} \mathrm{CFO}_{t}+b_{3} \mathrm{CFO}_{t+1}+b_{4} \Delta \mathrm{Sales}_{t}+b_{5} \mathrm{PPE}_{t}+\epsilon_{t} \text {, }
$$

where $\Delta W C_{t}$ is the change in working capital from year $t-1$ to year $t$. Specifically, it is computed as the increase in accounts receivable (Compustat item \# 302) plus the increase in inventory (item \# 303) minus the increase in accounts payable and accrued liabilities (item \# 304) minus the increase in taxes accrued (item \# 305) plus the increase (decrease) in other assets or liabilities (item \# 307). CFO is operating cash flow (item \# 308), $\Delta$ Sales $_{t}$ is the change in sales (item \# 12) from year $t-1$ to year $t$, and PPE is property, plant, and equipment (item \# 8). All variables are scaled by lagged total assets. Each year, this model is estimated for every firm using prior 8 years and the standard deviation of the residual is defined as the accruals quality. ${ }^{22}$ A larger standard deviation means lower accruals quality and lower accounting transparency. As is shown in Panel A, this alternative transparency measure not only confirms our main findings, but also produces stronger results. For example, the value-weighted alpha in the lowest tercile is $1.15 \%(t$-statistic $=2.97)$, which is larger than the corresponding value-weighted alpha in Table III.

In Panel B, we use E-index instead of G-index as an alternative measure of corporate governance. Bebchuk, Cohen, and Ferrell (2009) propose the E-index, which they base on the six most important provisions among the 24 of the G-index. They suggest that these six provisions are the key determinants of GIM's findings and hence a less noisy measure of corporate

\footnotetext{
$\overline{21}$ See also Dechow and Dichev (2002), Francis et al. (2005), and McNichols and Stubben (2011).

${ }^{22}$ We also estimate the model using prior 10 years or 12 years and the results do not change qualitatively.
} 


\section{Table VI. Robustness (1)}

This table reports abnormal returns for equal- and value-weighted Democracy-Dictatorship hedge portfolios using variants of regressions in Table III. In Panel A, accruals quality is used to measure firm transparency. It is constructed as the standard deviation of the residuals of the following regression model:

$$
\Delta W C_{t}=b_{0}+b_{1} \mathrm{CFO}_{t-1}+b_{2} \mathrm{CFO}_{t}+b_{3} \mathrm{CFO}_{t+1}+b_{4} \Delta \mathrm{Sales}_{t}+b_{5} \mathrm{PPE}_{t}+\epsilon_{t},
$$

where $\Delta W C_{t}$ is the change in working capital, CFO is cash from operations, $\Delta \operatorname{Sales}_{t}$ is change in sales, and PPE is property, plant, and equipment. All variables are scaled by lagged assets. Each year, this model is estimated for every firm using prior 8 years of data. In Panel B, we use E-index instead of G-index as an alternative measure of corporate governance. E-index is developed in Bebchuk, Cohen, and Ferrell (2009) and constructed based on 6 out of 24 corporate provisions. Firms with E-index value of zero are assigned to "Democracy Portfolio" and firms with E-index value of four or more are assigned to "Dictatorship Portfolio." In Panel C, "new economy" firms are excluded firms in the sample. "New economy" firms are classified in Hand (2003). In Panel D, we extend the sample period to 2011. In Panel E, results over the sample period of 2000-11 are reported. The sample period is from September 1990 to December 1999. $t$-statistics are reported in parentheses under the estimation coefficient. The significance levels $1 \%, 5 \%$, and $10 \%$ are denoted by $* * *, * *$, and $*$, respectively.

\begin{tabular}{|c|c|c|c|c|c|c|}
\hline & \multicolumn{3}{|c|}{ Equal-weighted hedge portfolio } & \multicolumn{3}{|c|}{ Value-weighted hedge portfolio } \\
\hline & $\begin{array}{l}\text { Lowest } \\
\text { tercile }\end{array}$ & $\begin{array}{l}\text { Medium } \\
\text { tercile }\end{array}$ & $\begin{array}{l}\text { Highest } \\
\text { tercile }\end{array}$ & $\begin{array}{l}\text { Lowest } \\
\text { tercile }\end{array}$ & $\begin{array}{l}\text { Medium } \\
\text { tercile }\end{array}$ & $\begin{array}{l}\text { Highest } \\
\text { tercile }\end{array}$ \\
\hline \multicolumn{7}{|c|}{ Panel A: Accruals quality } \\
\hline & $\begin{array}{l}0.82 * * * \\
(2.67)\end{array}$ & $\begin{array}{c}0.64 \\
(1.21)\end{array}$ & $\begin{array}{c}0.08 \\
(0.21)\end{array}$ & $\begin{array}{l}1.15^{* * * *} \\
(2.97)\end{array}$ & $\begin{array}{c}0.70 \\
(1.24)\end{array}$ & $\begin{array}{c}-0.16 \\
(0.34)\end{array}$ \\
\hline \multicolumn{7}{|l|}{ Panel B: E-index } \\
\hline Forecast error & $\begin{array}{l}0.83^{* * * *} \\
(4.79)\end{array}$ & $\begin{array}{c}0.34 * \\
(1.75)\end{array}$ & $\begin{array}{c}0.13 \\
(0.61)\end{array}$ & $\begin{array}{l}1.04 * * * \\
(3.50)\end{array}$ & $\begin{array}{c}0.56^{*} \\
(1.78)\end{array}$ & $\begin{array}{c}0.30 \\
(0.93)\end{array}$ \\
\hline Forecast dispersion & $\begin{array}{l}0.59 * * * \\
(3.00)\end{array}$ & $\begin{array}{c}0.19 \\
(0.95)\end{array}$ & $\begin{array}{c}0.08 \\
(0.33)\end{array}$ & $\begin{array}{l}0.97 * * * \\
(3.21)\end{array}$ & $\begin{array}{c}0.01 \\
(0.03)\end{array}$ & $\begin{array}{c}0.57 \\
(1.44)\end{array}$ \\
\hline Revision volatility & $\begin{array}{l}0.62 * * * \\
(3.42)\end{array}$ & $\begin{array}{c}0.12 \\
(0.64)\end{array}$ & $\begin{array}{c}0.23 \\
(1.14)\end{array}$ & $\begin{array}{l}0.79 * * * \\
(2.96)\end{array}$ & $\begin{array}{l}0.51^{* *} \\
(2.03)\end{array}$ & $\begin{array}{c}0.42 \\
(1.02)\end{array}$ \\
\hline \multicolumn{7}{|c|}{ Panel C: Excluding "new economy" } \\
\hline Forecast error & $\begin{array}{l}0.72 * * * \\
(2.65)\end{array}$ & $\begin{array}{c}0.21 \\
(0.75)\end{array}$ & $\begin{array}{l}-0.04 \\
(0.12)\end{array}$ & $\begin{array}{l}0.66^{* *} \\
(2.00)\end{array}$ & $\begin{array}{c}0.07 \\
(0.16)\end{array}$ & $\begin{array}{c}0.02 \\
(0.04)\end{array}$ \\
\hline Forecast dispersion & $\begin{array}{l}0.62 * * \\
(2.25)\end{array}$ & $\begin{array}{c}0.40 \\
(1.34)\end{array}$ & $\begin{array}{c}-0.12 \\
(0.39)\end{array}$ & $\begin{array}{l}0.65^{* *} \\
(2.00)\end{array}$ & $\begin{array}{c}0.36 \\
(0.79)\end{array}$ & $\begin{array}{c}-0.29 \\
(0.69)\end{array}$ \\
\hline Revision volatility & $\begin{array}{l}0.58^{* *} \\
(2.21) \\
\end{array}$ & $\begin{array}{c}0.09 \\
(0.35) \\
\end{array}$ & $\begin{array}{c}0.10 \\
(0.30) \\
\end{array}$ & $\begin{array}{c}0.48 \\
(1.33) \\
\end{array}$ & $\begin{array}{c}0.20 \\
(0.53) \\
\end{array}$ & $\begin{array}{c}0.27 \\
(0.62) \\
\end{array}$ \\
\hline \multicolumn{7}{|l|}{ Panel D: 1990-2011 } \\
\hline Forecast error & $\begin{array}{l}0.50^{* *} \\
(2.28)\end{array}$ & $\begin{array}{c}0.00 \\
(0.01)\end{array}$ & $\begin{array}{c}0.13 \\
(0.52)\end{array}$ & $\begin{array}{l}0.53 * * \\
(2.03)\end{array}$ & $\begin{array}{c}-0.26 \\
(0.73)\end{array}$ & $\begin{array}{c}0.17 \\
(0.37)\end{array}$ \\
\hline Forecast dispersion & $\begin{array}{l}0.48^{* *} \\
(2.23)\end{array}$ & $\begin{array}{l}-0.05 \\
(0.23)\end{array}$ & $\begin{array}{c}0.04 \\
(0.14)\end{array}$ & $\begin{array}{c}0.43 \\
(1.61)\end{array}$ & $\begin{array}{c}0.18 \\
(0.43)\end{array}$ & $\begin{array}{l}-0.24 \\
(0.64)\end{array}$ \\
\hline Revision volatility & $\begin{array}{c}0.34 \\
(1.55)\end{array}$ & $\begin{array}{c}0.00 \\
(0.01)\end{array}$ & $\begin{array}{c}0.20 \\
(0.83)\end{array}$ & $\begin{array}{c}0.25 \\
(0.89)\end{array}$ & $\begin{array}{c}0.03 \\
(0.10)\end{array}$ & $\begin{array}{c}0.45 \\
(1.14)\end{array}$ \\
\hline
\end{tabular}


Table VI. (Continued)

Equal-weighted hedge portfolio Value-weighted hedge portfolio

\begin{tabular}{llllll}
\hline $\begin{array}{l}\text { Lowest } \\
\text { tercile }\end{array}$ & $\begin{array}{l}\text { Medium } \\
\text { tercile }\end{array}$ & $\begin{array}{l}\text { Highest } \\
\text { tercile }\end{array}$ & $\begin{array}{l}\text { Lowest } \\
\text { tercile }\end{array}$ & $\begin{array}{l}\text { Medium } \\
\text { tercile }\end{array}$ & $\begin{array}{l}\text { Highest } \\
\text { tercile }\end{array}$
\end{tabular}

Panel E: $2000-11$

\begin{tabular}{lcccccc}
\hline Forecast error & 0.30 & 0.08 & -0.14 & 0.06 & -0.43 & -0.27 \\
& $(1.48)$ & $(0.22)$ & $(0.28)$ & $(0.13)$ & $(1.32)$ & $(0.91)$ \\
Forecast dispersion & 0.31 & -0.11 & -0.23 & -0.11 & 0.07 & -0.32 \\
& $(1.56)$ & $(1.66)$ & $(1.14)$ & $(0.67)$ & $(0.10)$ & $(0.45)$ \\
Revision volatility & 0.18 & 0.14 & 0.03 & -0.21 & 0.06 & -0.44 \\
& $(0.99)$ & $(0.40)$ & $(0.07)$ & $(0.66)$ & $(0.09)$ & $(0.68)$ \\
\hline
\end{tabular}

governance. Following Giroud and Mueller (2011), firms with E-index value of zero are assigned to "Democracy Portfolio" and firms with E-index value of four or more are assigned to "Dictatorship Portfolio." As is shown in the panel, the pattern of the alpha is very similar to what we obtain when we use the G-index. For instance, in the case of forecast error, the alpha estimated using equal-weighted portfolios is $0.83 \%$ and highly significant ( $t$-statistic $=4.79)$ in the lowest tercile, alpha is $0.34 \%$ and less significant ( $t$-statistic $=1.75)$ in the medium tercile, and it is $0.13 \%$ with no significance $(t$ statistic $=0.61)$ in the highest tercile. Observe that the pattern is not only similar for value-weighted portfolios, but also for the estimation results involving the other two transparency proxies. $^{23}$

Panels C and D of Table VI report abnormal returns for the other two robustness checks that rely again on the G-index. In Panel $\mathrm{C}$, we exclude firms that belong to the "new economy" group defined in Hand (2003). This group contains 274 Internet stocks. Core, Guay, and Rusticus (2006) show that the value-weighted abnormal return of the Democracy-Dictatorship hedge portfolio drops from $0.71 \%(t$-statistic $=2.73)$ to $0.46 \%$ with decreased significance $(t$-statistic $=1.83)$. Hence, the large abnormal returns might be driven by those new economy Internet firms. We check if similar patterns prevail in the sample without those firms. As is shown in Panel B, most of the alphas are large and highly significant in the lowest tercile, and all alphas are small and insignificant or marginally significant in

\footnotetext{
$\overline{23}$ In unreported tests, we find qualitatively identical results using only a $(0,1,2)$ count variable for poison pills and classified boards instead of the G-index. These provisions are commonly perceived as the two most effective takeover defenses and hence reinforce the takeover story. We thank the anonymous referee for suggesting this line of analysis.
} 
the medium and the highest terciles. Take forecast error as an example, the equal-weighted alpha is $0.72 \%$ and significant $(t$-statistic $=2.65)$ in the lowest tercile, it is $0.21 \%$ and insignificant $(t$-statistic $=0.75)$ in the medium tercile, and it is $-0.04 \%$ and insignificant $(t$-statistic $=0.12)$ in the highest tercile. Similar findings obtain for value-weighted hedge portfolios. However, comparing to our main results using the full sample, the magnitude and the significance of alphas drop especially in case of value-weighted portfolios, which is consistent with the results reported by Core, Guay, and Rusticus (2006).

In Panel D of Table VI, we extend the sample period to 2011. Prior studies find that the alpha drops when the sample period is extended. For example, Core, Guay, and Rusticus (2006) estimate a decrease to $0.40 \%$ in alpha $(t$-statistic $=1.68)$, when the sample period is extended to December 2003. Giroud and Mueller (2011) document that the value-weighted alpha drops to $0.24 \%$ and the equal-weighted alpha drops to $0.29 \%$ when their sample is extended to December 2006. The alpha of our extended sample drops to $0.23 \%(t$-statistic $=1.38)$ for the value-weighted hedge portfolio and to $0.32 \%(t$-statistic $=2.01)$ for the equal-weighted hedge portfolio (not reported). Even though the results for the extended sample are weaker, we still find similar abnormal return patterns when we divide the Democracy and Dictatorship portfolios into terciles based on the transparency proxies in some cases. Finally, Panel E of the table shows results for the 2000-11 period. Consistent with the recent literature (see, e.g., Bebchuk, Cohen, and Wang, 2011), the results disappear in the 2000s.

Table VII continues our robustness checks by investigating whether transparency is just correlated with other factors (e.g., institutional ownership or industry concentration) that are already known to be important, that is, we gather estimation results for these subsample tests, which help to rule out such an omitted variable story by showing that our result holds within these different subsamples. Put differently, this would suggest that transparency is independently important.

In Panels A and B of Table VII, we split the sample into firms with high and low institutional ownership, respectively. Institutional ownership is defined as the percentage of shares held by the 18 largest public pension funds listed in the appendix of Cremers and Nair (2005). ${ }^{24}$ We first divide Democracy and Dictatorship portfolios into equal-sized subgroups with high and low institutional ownership based on the level of firm's $13 \mathrm{~F}$ holdings data. The cutoff is the median of the distribution. This leaves us with four portfolios. Then, we

24 For these robustness tests, we retrieve and use the CDA/Spectrum Institutional (13F) Holdings data. 
Table VII. Robustness (2)

This table reports the abnormal returns for equal- and value-weighted DemocracyDictatorship hedge portfolios in various robustness checks. In Panel A, we restrict the sample to firms with high (above median) institutional ownership. In Panel B, we restrict the sample to firms with low (below median) institutional ownership. The institutional ownership is defined in Cremers and Nair (2005) as the percentage of shares held by the 18 largest public pension funds listed in their paper. In Panels C and D, the sample is split into firms in low and high competitive industries. The measure of industry competition is a sales-based HHI. It is computed as the sum of squared market shares for firms in each of the 48 FF industries. Market shares are computed using firms' sales data in Compustat. The sample period is from September 1990 to December 1999. $t$-statistics are reported in parentheses under the estimation coefficient. The significance levels $1 \%, 5 \%$, and $10 \%$ are denoted by $* * *, * *$, and *, respectively.

\begin{tabular}{|c|c|c|c|c|c|c|}
\hline & \multicolumn{3}{|c|}{ Equal-weighted hedge portfolio } & \multicolumn{3}{|c|}{ Value-weighted hedge portfolio } \\
\hline & $\begin{array}{l}\text { Lowest } \\
\text { tercile }\end{array}$ & $\begin{array}{l}\text { Medium } \\
\text { tercile }\end{array}$ & $\begin{array}{l}\text { Highest } \\
\text { tercile }\end{array}$ & $\begin{array}{l}\text { Lowest } \\
\text { tercile }\end{array}$ & $\begin{array}{l}\text { Medium } \\
\text { tercile }\end{array}$ & $\begin{array}{l}\text { Highest } \\
\text { tercile }\end{array}$ \\
\hline \multicolumn{7}{|c|}{ Panel A: High inst. ownership } \\
\hline Forecast error & $\begin{array}{l}1.08^{* * * *} \\
(3.11)\end{array}$ & $\begin{array}{c}0.34 \\
(0.95)\end{array}$ & $\begin{array}{c}0.24 \\
(0.59)\end{array}$ & $\begin{array}{l}1.41^{* * *} \\
(3.67)\end{array}$ & $\begin{array}{l}1.28^{* * *} \\
(2.91)\end{array}$ & $\begin{array}{l}-0.12 \\
(0.19)\end{array}$ \\
\hline Forecast dispersion & $\begin{array}{l}1.14 * * * \\
(2.77)\end{array}$ & $\begin{array}{c}0.25 \\
(0.74)\end{array}$ & $\begin{array}{c}0.39 \\
(0.96)\end{array}$ & $\begin{array}{l}1.54 * * * \\
(3.53)\end{array}$ & $\begin{array}{c}0.80 \\
(1.65)\end{array}$ & $\begin{array}{c}0.28 \\
(0.47)\end{array}$ \\
\hline Revision volatility & $\begin{array}{l}0.95^{* *} \\
(2.45)\end{array}$ & $\begin{array}{c}0.02 \\
(0.06)\end{array}$ & $\begin{array}{c}0.53 \\
(1.47)\end{array}$ & $\begin{array}{l}1.46^{* * *} \\
(3.18)\end{array}$ & $\begin{array}{c}0.27 \\
(0.62)\end{array}$ & $\begin{array}{c}0.91 \\
(1.59)\end{array}$ \\
\hline \multicolumn{7}{|c|}{ Panel B: Low inst. ownership } \\
\hline Forecast error & $\begin{array}{c}0.67 \\
(1.50)\end{array}$ & $\begin{array}{c}-0.03 \\
(0.07)\end{array}$ & $\begin{array}{l}-0.29 \\
(0.61)\end{array}$ & $\begin{array}{c}0.56 \\
(1.14)\end{array}$ & $\begin{array}{c}0.16 \\
(0.31)\end{array}$ & $\begin{array}{l}-0.42 \\
(0.86)\end{array}$ \\
\hline Forecast dispersion & $\begin{array}{c}0.58^{*} \\
(1.75)\end{array}$ & $\begin{array}{c}0.22 \\
(0.45)\end{array}$ & $\begin{array}{l}-0.17 \\
(0.34)\end{array}$ & $\begin{array}{c}0.27 \\
(0.61)\end{array}$ & $\begin{array}{l}-0.16 \\
(0.31)\end{array}$ & $\begin{array}{l}-0.40 \\
(0.73)\end{array}$ \\
\hline Revision volatility & $\begin{array}{c}0.28 \\
(0.85)\end{array}$ & $\begin{array}{c}0.35 \\
(0.84)\end{array}$ & $\begin{array}{c}-0.13 \\
(0.27)\end{array}$ & $\begin{array}{c}0.27 \\
(0.58)\end{array}$ & $\begin{array}{l}-0.10 \\
(0.21)\end{array}$ & $\begin{array}{l}-0.49 \\
(0.85)\end{array}$ \\
\hline \multicolumn{7}{|c|}{ Panel C: Low industry competition } \\
\hline Forecast error & $\begin{array}{l}0.86^{* * * *} \\
(2.66)\end{array}$ & $\begin{array}{c}0.41 \\
(1.10)\end{array}$ & $\begin{array}{c}0.01 \\
(0.02)\end{array}$ & $\begin{array}{l}1.97^{* * *} \\
(3.94)\end{array}$ & $\begin{array}{c}0.24 \\
(0.40)\end{array}$ & $\begin{array}{c}0.39 \\
(0.53)\end{array}$ \\
\hline Forecast dispersion & $\begin{array}{l}0.95 * * \\
(2.53)\end{array}$ & $\begin{array}{c}0.06 \\
(0.15)\end{array}$ & $\begin{array}{c}0.39 \\
(0.05)\end{array}$ & $\begin{array}{l}1.97^{* * * *} \\
(3.68)\end{array}$ & $\begin{array}{c}0.44 \\
(0.75)\end{array}$ & $\begin{array}{c}0.46 \\
(0.56)\end{array}$ \\
\hline Revision volatility & $\begin{array}{l}0.79 * * \\
(2.07)\end{array}$ & $\begin{array}{c}0.23 \\
(0.55)\end{array}$ & $\begin{array}{c}0.28 \\
(0.49)\end{array}$ & $\begin{array}{l}1.42^{* * *} \\
(2.73)\end{array}$ & $\begin{array}{c}0.35 \\
(0.58)\end{array}$ & $\begin{array}{c}0.96 \\
(1.46)\end{array}$ \\
\hline \multicolumn{7}{|c|}{ Panel D: High industry competition } \\
\hline Forecast error & $\begin{array}{l}0.74 * * \\
(2.38)\end{array}$ & $\begin{array}{c}0.44 \\
(1.41)\end{array}$ & $\begin{array}{l}-0.01 \\
(0.02)\end{array}$ & $\begin{array}{c}0.69 * \\
(1.89)\end{array}$ & $\begin{array}{c}0.38 \\
(0.98)\end{array}$ & $\begin{array}{l}-0.20 \\
(0.47)\end{array}$ \\
\hline Forecast dispersion & $\begin{array}{l}0.72 * * \\
(2.40)\end{array}$ & $\begin{array}{c}0.55^{*} \\
(1.87)\end{array}$ & $\begin{array}{l}-0.09 \\
(0.27)\end{array}$ & $\begin{array}{c}0.62 * \\
(1.70)\end{array}$ & $\begin{array}{c}0.33 \\
(0.73)\end{array}$ & $\begin{array}{l}-0.31 \\
(0.82)\end{array}$ \\
\hline Revision volatility & $\begin{array}{l}0.78 * * \\
(2.54)\end{array}$ & $\begin{array}{c}0.05 \\
(0.15)\end{array}$ & $\begin{array}{c}0.33 \\
(0.98)\end{array}$ & $\begin{array}{c}0.67^{*} \\
(1.73)\end{array}$ & $\begin{array}{c}0.06 \\
(0.18)\end{array}$ & $\begin{array}{c}0.36 \\
(0.83)\end{array}$ \\
\hline
\end{tabular}


split each of these four portfolios into three equal-sized subgroups based on each of the three transparency proxies. For each transparency measure, we end up with 12 portfolios: 6 with high institutional ownership and 6 with low institutional ownership. We again form hedge portfolios and estimate Cahart's four-factor model within these subgroups.

Cremers and Nair (2005) find that the Democracy-Dictatorship portfolio earns significant abnormal return only for the group including firms with high institutional ownership. Our results are consistent with their findings in both cases of value- and equal-weighted portfolios. In the case of forecast error, for example, the value-weighted alpha is $1.41 \%$ with a $t$-statistic of 3.67 in the lowest tercile of the group with high institutional ownership, whereas it is $0.56 \%$ with a $t$-statistic of 1.14 in the lowest tercile of the group with low institutional ownership. In the case of forecast dispersion, the value-weighted alpha is $1.54 \%$ with a $t$-statistic of 3.53 in the lowest tercile of the group with high institutional ownership, whereas it is $0.27 \%$ with a $t$-statistic of 0.61 in the lowest tercile of the group with low institutional ownership. Similar insights arise in the case of revision volatility. More importantly, these results are confirming our main findings. For the high institutional ownership group, we obtain large and significant estimates for alpha in the lowest tercile and smaller and insignificant or marginally significant alphas in the medium and the highest terciles. This is true for all the three transparency proxies. For example, in the case of forecast error, the trading strategy in the lowest tercile earns an equal-weighted abnormal return of $1.08 \%$ at the $1 \%$ significance level $(t$-statistic $=3.11)$, whereas the alpha in the medium tercile is $0.34 \%$ with no significance ( $t$-statistic $=0.95$ ), and the estimated abnormal return in the highest tercile is $0.24 \%$ with no significance $(t$-statistic $=0.59)$.

In Panels C and D of Table VII, we split the sample into firms in industries with low and high product market competition to verify that our findings are not driven by product market competition. Giroud and Mueller (2011) establish significant abnormal returns of the Democracy-Dictatorship portfolio in the subgroup that includes firms in less competitive industries and conclude that firms in concentrated industries benefit more from good corporate governance. To examine whether our results are largely due to industry competition, we employ a sales-based Herfindahl-Hirschman index (HHI) to proxy for industry competition. Following Giroud and Mueller (2011), we compute HHI as the sum of squared market shares for firms in each of the 48 Fama and French (1997, FF) industries. Market shares are computed using firms' sales data from Compustat. We 1st divide Democracy and Dictatorship portfolios into two equal-sized subgroups with high and low industry competition based on the level of the 
HHI. This leaves us with four portfolios. Then, we divide each of these four portfolios into three equal-sized subgroups based on the three transparency proxies. Thus, we end up with 12 portfolios: 6 with low industry competition and 6 with high industry competition. We again form the DemocracyDictatorship hedge portfolios and estimate the four-factor model within the low- and the high industry competition subgroups.

Panel C of Table VII presents the estimated alphas for the portfolios formed in concentrated industries (i.e., industries with lower competition or higher values of HHI). Again, our estimates of abnormal returns show similar patterns as in our main results. Alpha is always large and significant in the lowest tercile and smaller and insignificant or marginally significant in the medium and the highest tercile. For instance, in the case of forecast dispersion, the equal-weighted alpha is $0.95 \%$ and significant ( $t$-statistic $=2.53)$ in the lowest tercile, and it is $0.39 \%$ and insignificant ( $t$-statistic $=0.05)$ in the highest tercile. Perhaps surprisingly, the value-weighted alpha is $1.97 \%$ and significant $(t$-statistic $=3.68)$ in the lowest tercile, and it is $0.46 \%$ and insignificant $(t$-statistic $=0.56)$ in the highest tercile. Panel D presents the estimated alphas for the portfolios formed in competitive industries (i.e., industries with higher competition or lower values of HHI). In this subsample, our baseline findings are still valid, but, as expected, economic magnitudes and statistical significance levels are smaller than in concentrated industries. Consistent with Giroud and Mueller (2011), the transparency-related patterns of abnormal returns are diminished in Panel D relative to Panel C. Intuitively, a higher level of product market competition is a substitute for governance and hence weakens the effect of corporate governance on equity prices. In sum, this set of robustness tests also supports our main findings.

Table VIII presents the results for the final set of robustness checks. In this table, we study how our findings are affected by firm characteristics, such as financial leverage and firm size, which could be correlated with transparency and hence explain our result. In Panels A and B, we split the sample into firms with a low (below-median) leverage ratio and a high (above-median) leverage ratio, respectively. It has been argued that high leverage reduces the probability of the takeover (see, e.g., Stulz, 1988; Novaes, 2003; Zwiebel, 1996; Harris and Raviv, 1998). Thus, firms with high levels of debt are more difficult to be taken over, even though they may have fewer anti-takeover and shareholder rights provisions. This suggests that corporate governance should be more effective among low leverage firms. Comparison of the results in Panels A and B provides support for this view. For example, in case of forecast error, the value-weighted alpha is $1.67 \%$ with a $t$-statistic of 4.51 in the lowest tercile of the low leverage group, whereas it is $1.05 \%$ with a 


\section{Table VIII. Robustness (3)}

This table continues reporting the abnormal returns for various robustness checks. In Panel A, we restrict the sample to firms with low (below-median) leverage ratio. In Panel B, we restrict the sample to firms with high (above-median) leverage ratio. Leverage ratio is defined as the long-term debt divided by firm assets value. In Panels C and D, the sample is divided into low (below-median) and high (above-median) asset groups. The sample period is from September 1990 to December 1999. $t$-statistics are reported in parentheses under the estimation coefficient. The significance levels $1 \%, 5 \%$, and $10 \%$ are denoted by $* * *, * *$, and $*$, respectively.

\begin{tabular}{|c|c|c|c|c|c|c|}
\hline & \multicolumn{3}{|c|}{ Equal-weighted hedge portfolio } & \multicolumn{3}{|c|}{ Value-weighted hedge portfolio } \\
\hline & $\begin{array}{l}\text { Lowest } \\
\text { tercile }\end{array}$ & $\begin{array}{l}\text { Medium } \\
\text { tercile }\end{array}$ & $\begin{array}{l}\text { Highest } \\
\text { tercile }\end{array}$ & $\begin{array}{l}\text { Lowest } \\
\text { tercile }\end{array}$ & $\begin{array}{l}\text { Medium } \\
\text { tercile }\end{array}$ & $\begin{array}{l}\text { Highest } \\
\text { tercile }\end{array}$ \\
\hline \multicolumn{7}{|c|}{ Panel A: Low leverage ratio firm } \\
\hline Forecast error & $\begin{array}{l}0.94 * * \\
(2.27)\end{array}$ & $\begin{array}{c}0.20 \\
(0.50)\end{array}$ & $\begin{array}{c}0.20 \\
(0.50)\end{array}$ & $\begin{array}{l}1.67 * * * \\
(4.51)\end{array}$ & $\begin{array}{c}0.64 \\
(1.35)\end{array}$ & $\begin{array}{c}0.16 \\
(0.30)\end{array}$ \\
\hline Forecast dispersion & $\begin{array}{l}0.75^{* *} \\
(1.98)\end{array}$ & $\begin{array}{c}0.34 \\
(0.65)\end{array}$ & $\begin{array}{c}0.27 \\
(0.68)\end{array}$ & $\begin{array}{l}1.58^{* * * *} \\
(3.53)\end{array}$ & $\begin{array}{c}0.39 \\
(0.86)\end{array}$ & $\begin{array}{c}0.40 \\
(0.70)\end{array}$ \\
\hline Revision volatility & $\begin{array}{l}0.87^{* * *} \\
(2.48)\end{array}$ & $\begin{array}{l}-0.03 \\
(0.06)\end{array}$ & $\begin{array}{c}0.51 \\
(1.17)\end{array}$ & $\begin{array}{l}1.22 * * \\
(2.55)\end{array}$ & $\begin{array}{c}0.26 \\
(0.56)\end{array}$ & $\begin{array}{c}0.62 \\
(1.15)\end{array}$ \\
\hline \multicolumn{7}{|c|}{ Panel B: High leverage ratio firm } \\
\hline Forecast error & $\begin{array}{l}1.03 * * \\
(2.39)\end{array}$ & $\begin{array}{c}0.78^{*} \\
(1.81)\end{array}$ & $\begin{array}{l}-0.04 \\
(0.10)\end{array}$ & $\begin{array}{l}1.05^{* *} \\
(2.41)\end{array}$ & $\begin{array}{c}0.99 * \\
(1.87)\end{array}$ & $\begin{array}{l}-0.02 \\
(0.04)\end{array}$ \\
\hline Forecast dispersion & $\begin{array}{l}1.35^{* * *} \\
(3.35)\end{array}$ & $\begin{array}{c}0.31 \\
(0.82)\end{array}$ & $\begin{array}{c}0.11 \\
(0.23)\end{array}$ & $\begin{array}{l}1.13^{* * * *} \\
(2.84)\end{array}$ & $\begin{array}{c}0.58 \\
(1.00)\end{array}$ & $\begin{array}{c}0.09 \\
(0.15)\end{array}$ \\
\hline Revision volatility & $\begin{array}{l}0.97 * * \\
(2.49)\end{array}$ & $\begin{array}{c}1.01 \\
(1.53)\end{array}$ & $\begin{array}{c}0.34 \\
(0.33)\end{array}$ & $\begin{array}{l}0.97 * * \\
(2.42)\end{array}$ & $\begin{array}{l}0.65^{* *} \\
(2.06)\end{array}$ & $\begin{array}{c}0.15 \\
(0.58)\end{array}$ \\
\hline \multicolumn{7}{|c|}{ Panel C: Small asset firm } \\
\hline Forecast error & $\begin{array}{l}1.44 * * * \\
(2.63)\end{array}$ & $\begin{array}{c}0.58 \\
(1.42)\end{array}$ & $\begin{array}{c}0.26 \\
(0.63)\end{array}$ & $\begin{array}{l}1.59 * * * \\
(2.60)\end{array}$ & $\begin{array}{c}0.83 \\
(1.50)\end{array}$ & $\begin{array}{c}0.04 \\
(0.06)\end{array}$ \\
\hline Forecast dispersion & $\begin{array}{l}1.58 * * * \\
(2.77)\end{array}$ & $\begin{array}{c}0.57 \\
(1.54)\end{array}$ & $\begin{array}{c}0.14 \\
(0.33)\end{array}$ & $\begin{array}{l}1.79 * * * \\
(2.96)\end{array}$ & $\begin{array}{c}0.46 \\
(0.82)\end{array}$ & $\begin{array}{l}-0.03 \\
(0.05)\end{array}$ \\
\hline Revision volatility & $\begin{array}{l}1.13 * * * \\
(2.62)\end{array}$ & $\begin{array}{c}0.65 \\
(1.35)\end{array}$ & $\begin{array}{c}0.51 \\
(1.13)\end{array}$ & $\begin{array}{l}1.74 * * * \\
(2.76)\end{array}$ & $\begin{array}{c}0.07^{*} \\
(0.13)\end{array}$ & $\begin{array}{c}0.59 \\
(1.05)\end{array}$ \\
\hline \multicolumn{7}{|c|}{ Panel D: Large asset firm } \\
\hline Forecast error & $\begin{array}{c}0.47 \\
(1.57)\end{array}$ & $\begin{array}{c}0.21 \\
(0.54)\end{array}$ & $\begin{array}{c}0.11 \\
(0.27)\end{array}$ & $\begin{array}{l}0.92 * * * \\
(2.58)\end{array}$ & $\begin{array}{c}0.76 \\
(1.53)\end{array}$ & $\begin{array}{l}-0.11 \\
(0.19)\end{array}$ \\
\hline Forecast dispersion & $\begin{array}{l}0.80^{* * *} \\
(2.41)\end{array}$ & $\begin{array}{c}0.07 \\
(0.18)\end{array}$ & $\begin{array}{l}-0.07 \\
(0.17)\end{array}$ & $\begin{array}{l}1.03^{* *} \\
(2.44)\end{array}$ & $\begin{array}{c}0.16 \\
(0.31)\end{array}$ & $\begin{array}{c}0.49 \\
(1.02)\end{array}$ \\
\hline Revision volatility & $\begin{array}{c}0.51 \\
(1.43)\end{array}$ & $\begin{array}{c}0.09 \\
(0.25)\end{array}$ & $\begin{array}{c}0.19 \\
(0.52)\end{array}$ & $\begin{array}{l}1.08^{* *} \\
(2.48)\end{array}$ & $\begin{array}{c}0.02 \\
(0.06)\end{array}$ & $\begin{array}{l}1.00 \\
(2.00)\end{array}$ \\
\hline
\end{tabular}


$t$-statistic of 2.41 in the lowest tercile of the high leverage group. In case of forecast dispersion, the value-weighted alpha is $1.58 \%$ with a $t$-statistic of 3.53 in the lowest tercile of the group with low leverage, whereas it is $1.13 \%$ with a $t$-statistic of 2.84 in the lowest tercile of the group with high leverage. Similar results arise for revision volatility. More importantly, these results from both panels confirm our main findings. In all cases and for both groups, we obtain large and significant alphas in the lowest tercile and smaller and insignificant alphas in the highest tercile.

In Panels C and D of Table VIII, we split the sample into firms with low (below-median) asset value and to firms with high (above-median) asset value, respectively. Motivated by the view that large (target) firms require bidders to spend more effort and resources and thus firm size has a deterrent role for takeovers, governance mechanisms should be more effective for smaller firms. The results in Panels $\mathrm{C}$ and $\mathrm{D}$ confirm this view. The alphas in the lowest tercile in all cases in Panel C are economically larger than the corresponding alphas in the lowest tercile in Panel D. For instance, in the case of forecast error, the value-weighted alpha is $1.59 \%$ with a $t$-statistic of 2.60 in the lowest tercile of the small firm group, whereas it is $0.92 \%$ with a $t$-statistic of 2.58 in the lowest tercile of the large firm group. In sum, this set of subsample studies not only confirms our main findings, but also provides support for the idea that the effectiveness of the governance mechanisms can be affected by factors that have an impact on the takeover probability. That is, transparency matters more for smaller firms, but again these tests suggest that transparency is independently important, because it also matters for larger firms.

\subsection{INDUSTRY EFFECTS}

In this section, we adjust for industry effects. It is very important because some industries tend to have high abnormal returns and some tend to have low abnormal returns (see, e.g., Hou and Robinson, 2006). If a large part of the Democracy portfolio is formed by firms from high abnormal return industries, and a large part of the Dictatorship portfolio is formed by firms from low abnormal return industries, this could be one possible source of the large and significant abnormal returns in our findings. Thus, we re-estimate the regression using industry-adjusted returns, which are obtained by subtracting the median monthly industry return from the individual firm's monthly return. The median industry return is calculated in each of the $48 \mathrm{FF}$ industries using all firms in the CRSP universe. These estimation results are presented in Table IX.

As is shown by the table, adjusting for industry returns does not weaken our previous findings. That is, similar patterns appear again for all of the 
Table IX. Industry effects

This table reports the alphas of the trading strategy using industry-adjusted returns, which are obtained by subtracting the median industry returns from the individual firm's return. The industry return is calculated in each of the 48 FF industries. In Panel A, the FamaFrench three-factor model is used. In Panel B, the Carhart four-factor model is employed. The sample period is from September 1990 to December 1999. $t$-statistics are reported in parentheses under the estimation coefficient. The significance levels $1 \%, 5 \%$, and $10 \%$ are denoted by $* * *, * *$, and $*$, respectively.

\begin{tabular}{|c|c|c|c|c|c|c|}
\hline & \multicolumn{3}{|c|}{ Equal-weighted hedge portfolio } & \multicolumn{3}{|c|}{ Value-weighted hedge portfolio } \\
\hline & $\begin{array}{l}\text { Lowest } \\
\text { tercile }\end{array}$ & $\begin{array}{l}\text { Medium } \\
\text { tercile }\end{array}$ & $\begin{array}{l}\text { Highest } \\
\text { tercile }\end{array}$ & $\begin{array}{l}\text { Lowest } \\
\text { tercile }\end{array}$ & $\begin{array}{l}\text { Medium } \\
\text { tercile }\end{array}$ & $\begin{array}{l}\text { Highest } \\
\text { tercile }\end{array}$ \\
\hline \multicolumn{7}{|c|}{ Panel A: Fama-French three-factor model with industry-adjusted returns } \\
\hline Forecast error & $\begin{array}{l}0.77 * * * \\
(3.00)\end{array}$ & $\begin{array}{l}0.15^{* *} \\
(2.14)\end{array}$ & $\begin{array}{c}-0.15 \\
(1.21)\end{array}$ & $\begin{array}{l}1.20 * * * \\
(3.33)\end{array}$ & $\begin{array}{l}-0.34 \\
(0.88)\end{array}$ & $\begin{array}{l}-0.52 \\
(1.37)\end{array}$ \\
\hline Forecast dispersion & $\begin{array}{l}0.69 * * * \\
(2.99)\end{array}$ & $\begin{array}{c}0.26 \\
(0.96)\end{array}$ & $\begin{array}{l}-0.15 \\
(0.57)\end{array}$ & $\begin{array}{l}0.86^{* * * *} \\
(2.80)\end{array}$ & $\begin{array}{c}0.01 \\
(0.03)\end{array}$ & $\begin{array}{l}-0.42 \\
(1.06)\end{array}$ \\
\hline Revision volatility & $\begin{array}{l}0.62 * * * \\
(2.69)\end{array}$ & $\begin{array}{c}0.03 \\
(0.14)\end{array}$ & $\begin{array}{c}0.13 \\
(0.49)\end{array}$ & $\begin{array}{c}0.75^{*} \\
(1.97)\end{array}$ & $\begin{array}{l}-0.13 \\
(0.39)\end{array}$ & $\begin{array}{c}0.24 \\
(0.60)\end{array}$ \\
\hline \multicolumn{7}{|c|}{ Panel B: Carhart four-factor model with industry-adjusted returns } \\
\hline Forecast error & $\begin{array}{l}0.81 * * * \\
(3.35)\end{array}$ & $\begin{array}{c}0.19 \\
(0.84)\end{array}$ & $\begin{array}{l}-0.05 \\
(0.21)\end{array}$ & $\begin{array}{l}1.20^{* * * *} \\
(3.28)\end{array}$ & $\begin{array}{c}0.36 \\
(0.92)\end{array}$ & $\begin{array}{l}-0.46 \\
(1.20)\end{array}$ \\
\hline Forecast dispersion & $\begin{array}{l}0.70^{* * * *} \\
(3.01)\end{array}$ & $\begin{array}{c}0.32 \\
(1.23)\end{array}$ & $\begin{array}{l}-0.05 \\
(0.18)\end{array}$ & $\begin{array}{l}0.85^{* * *} \\
(2.74)\end{array}$ & $\begin{array}{c}0.03 \\
(0.06)\end{array}$ & $\begin{array}{l}-0.34 \\
(0.88)\end{array}$ \\
\hline Revision volatility & $\begin{array}{l}0.63^{* * * *} \\
(2.73)\end{array}$ & $\begin{array}{c}0.09 \\
(0.35)\end{array}$ & $\begin{array}{c}0.25 \\
(0.97)\end{array}$ & $\begin{array}{c}0.73^{*} \\
(1.88)\end{array}$ & $\begin{array}{l}-0.09 \\
(0.28)\end{array}$ & $\begin{array}{c}0.31 \\
(0.77)\end{array}$ \\
\hline
\end{tabular}

three modified regression models. In Panel B, for example, we estimate the Carhart four-factor model with industry-adjusted returns. We again find large and significant alphas in the lowest tercile, smaller and insignificant or marginally significant returns in the medium and the highest terciles for both equal- and value-weighted portfolios. Notice that, in the case of forecast error and equal-weighted returns, the alpha is $0.81 \%$ and significant $(t$-statistic $=3.35)$ in the lowest tercile, it is $0.19 \%$ and insignificant ( $t$-statistic $=0.84)$ in the medium tercile, and it is $-0.05 \%$ and insignificant ( $t$-statistic $=0.21)$ in the highest tercile.

\subsection{FAMA-MACBETH RETURN REGRESSIONS}

In this section, we follow the literature by testing our hypothesis using standard Fama-MacBeth return regressions with a set of control variables 
and find supportive evidence for our main result. In order to identify the effect of corporate governance on stock returns in different transparency groups, we create a dummy variable for the tercile of firm's transparency and interact it with the Democracy dummy. So, we estimate the following model:

$$
R_{i t}=\alpha_{t}+\beta_{1 t}\left(D_{i t} \times A 1_{\mathrm{it}}\right)+\beta_{2 t}\left(D_{\mathrm{it}} \times A 2_{\mathrm{it}}\right)+\beta_{3 t}\left(D_{\mathrm{it}} \times A 3_{\mathrm{it}}\right)+\gamma_{t} \mathbf{Z}_{\mathrm{it}}+\epsilon_{\mathrm{it}},
$$

where $R_{\mathrm{it}}$ is the month $t$ stock return of firm $i, D_{\mathrm{it}}$ is the Democracy dummy (which equals to one if the firm is in the Democracy portfolio and equals to zero if the firm is in the Dictatorship portfolio), $A 1_{\text {it }}$ is a dummy variable for the lowest tercile of the analyst variable, $A 2_{\text {it }}$ is a dummy variable for the medium tercile, $A 3_{\text {it }}$ is a dummy variable for the highest tercile, and $\mathbf{Z}_{\text {it }}$ is a vector of control variables. Following GIM, the elements of $\mathbf{Z}_{\text {it }}$ include book-to-market ratio, gross return from month $t-3$ to month $t-2$, gross return from month $t-6$ to month $t-4$, gross return from month $t-12$ to month $t-7$, firm size, leverage, stock price, sales growth over previous 5 years, trading volume of New York Stock Exchange (NYSE) or Amex stocks, trading volume of National Association of Securities Dealers Automated Quotations (NASDAQ) stocks, a NASDAQ dummy, an S\&P 500 dummy, dividend yield, institutional ownership, product market competition (measured by a sales-based HHI), and firm idiosyncratic volatility. All explanatory variables are lagged. The control variables also include dummies of the analyst variables to account for the direct effect of the transparency terciles. We control for firm idiosyncratic volatility because Ferreira and Laux (2007) argue that firms with lower level of G-index show higher idiosyncratic volatility. We estimate Equation (3) every month over the period from September 1990 to December 1999 and report the mean of the monthly estimate of the coefficients for relevant variables. ${ }^{25}$

Table X summarizes the results. In Column [1], G-index is used as the measure of corporate governance and a sample with all firms is used in the monthly cross-sectional regression. As is shown, the coefficient on G-index is -0.03 . Although the sign is what we expect to show the positive impact of good governance on stock returns, the magnitude is small and the statistical

\footnotetext{
25 The idea of the regression specification here is to estimate the impact of corporate governance on stock returns across different transparency groups. Thus, it is not necessary to include an extra term for the G-index dummy to identify the governance effect again. In order to control for any direct effect from transparency on stock returns, we also include dummy variables for high and medium transparency terciles. The low transparency tercile's dummy variable is not included because of redundancy - a similar specification is employed in Giroud and Mueller (2011).
} 


\section{Table $X$. Fama-MacBeth return regressions}

This table summarizes Fama-MacBeth estimates from monthly cross-sectional regressions of individual stock returns on an intercept, either the G-index or a Democracy dummy or the interaction terms between the Democracy dummy and transparency dummies along with a set of control variables. The estimated model is given in Equation (3) (see Section 5.3). The Democracy dummy equals one, if the firm is in the Democracy portfolio. It equals zero, if the firm is in the Dictatorship portfolio. Control variables include book-to-market ratio, gross return from month $t-3$ to month $t-2$, gross return from month $t-6$ to month $t-4$, gross return from month $t-12$ to month $t-7$, firm size, book leverage, stock price, sales growth over previous 5 years, trading volume of NYSE or Amex stocks, trading volume of NASDAQ stocks, a NASDAQ dummy, an S\&P 500 dummy, dividend yield, institutional ownership, product market competition (measured by a sales-based HHI), and firm idiosyncratic volatility. The definition of these variables can be found in the appendix in GIM. All explanatory variables are lagged. For Brevity, the coefficients on the control variables are not reported. Column [1] uses the full sample and Columns [2-5] use the sample, including only Democracy and Dictatorship firms. Column [1] reports the coefficient on G-index. Column [2] reports the coefficient on the Democracy dummy. Column [3] reports the coefficients on interaction terms when forecast dispersion is used for the transparency dummies. Column [4] reports the coefficients on interaction terms when forecast error is used for the transparency dummies. Column [5] reports the coefficients on interaction terms when revision volatility is used for the transparency dummies. The sample period is from September 1990 to December 1999. $t$-statistics are reported in parentheses under the estimation coefficient. The significance levels $1 \%, 5 \%$, and $10 \%$ are denoted by $* * *, * *$, and $*$, respectively.

\begin{tabular}{|c|c|c|c|c|c|}
\hline & [1] & [2] & [3] & [4] & [5] \\
\hline G-index & $\begin{array}{c}-0.03 \\
(1.45)\end{array}$ & & & & \\
\hline Democracy & & $\begin{array}{c}0.34 \\
(1.51)\end{array}$ & & & \\
\hline Democracy $\times$ lowest & & & $\begin{array}{l}0.64 * * \\
(2.43)\end{array}$ & $\begin{array}{l}0.76^{* * * *} \\
(2.66)\end{array}$ & $\begin{array}{l}0.78^{* * * *} \\
(2.80)\end{array}$ \\
\hline Democracy $\times$ medium & & & $\begin{array}{c}0.27 \\
(1.10)\end{array}$ & $\begin{array}{l}-0.12 \\
(0.40)\end{array}$ & $\begin{array}{c}-0.12 \\
(0.41)\end{array}$ \\
\hline Democracy $\times$ highest & & & $\begin{array}{l}-0.43 \\
(1.25)\end{array}$ & $\begin{array}{l}-0.29 \\
(0.82)\end{array}$ & $\begin{array}{l}0.26 \\
(0.82)\end{array}$ \\
\hline Lowest tercile & & & $\begin{array}{l}0.62 * * \\
(2.12)\end{array}$ & $\begin{array}{c}0.44 \\
(1.45)\end{array}$ & $\begin{array}{l}0.73 * * \\
(2.33)\end{array}$ \\
\hline Medium tercile & & & $\begin{array}{c}0.16 \\
(0.64)\end{array}$ & $\begin{array}{c}0.48^{*} \\
(1.88)\end{array}$ & $\begin{array}{c}0.31 \\
(1.15)\end{array}$ \\
\hline Number of observations & 124,052 & 19,467 & 19,467 & 19,467 & 19,467 \\
\hline Number of months & 112 & 112 & 112 & 112 & 112 \\
\hline
\end{tabular}

significance is low ( $t$-statistic $=1.45)$. This is consistent with the results in GIM. In Column [2], we restrict the sample to firms in the Democracy and Dictatorship portfolios and use a Democracy dummy to proxy for corporate governance. This is consistent with the way the Democracy-Dictatorship 
portfolio is constructed in the prior analysis. As displayed in the table, the coefficient estimate on the Democracy dummy is 0.34 , but insignificant ( $t$ statistic $=1.51)$. It means that, on average, a Democracy firm can earn a $0.34 \%$ higher monthly return than a Dictatorship firm, if all other firm characteristics are the same. In Column [3], the Democracy dummy is interacted with three transparency dummies (using forecast dispersion) to identify the differential effect of corporate governance on stock returns for different transparency groups. The results also support our main finding. That is, the coefficient on the interaction term for the lowest tercile is 0.64 and significant $(t$-statistic $=2.43)$, the coefficient on the interaction term for the medium tercile is 0.27 and insignificant $(t$-statistic $=1.10)$, and the coefficient on the interaction term for the highest tercile is -0.43 and insignificant ( $t$-statistic $=1.25$ ). Similar patterns prevail in Columns [4] and [5], where we replace forecast dispersion by forecast error and revision volatility, respectively. Taken together, these Fama-MacBeth regression results reinforce our baseline results.

\subsection{ALTERNATIVE ASSET PRICING MODELS}

In this section, we further estimate the abnormal returns of the trading strategy using alternative asset pricing models. The results are reported in Table XI. In Panel A, we replace the Carhart four-factor model with the market (or capital asset pricing model) model. As is shown in the table, the alphas for the transparent group are positive and significant for both equaland value-weighted portfolios, whereas the alphas for the opaque group are small and insignificant. This is consistent with our main hypothesis. However, the results are weaker in terms of both magnitude and statistical significance. This is consistent with Giroud and Mueller (2011), who also find weaker results when using market model, perhaps because the Democracy-Dictatorship hedge portfolios have significant and negative loadings on both size and value factor. As seen in Panel A of Table II, both GIM and our replication results reveal that the hedge portfolios load negatively on size and value factor, so excluding these factors in the regression model will result in a less positive intercept.

In Panel B, we use the Fama-French four-factor model to replace the Carhart four-factor model. The two models are almost the same. They share the same market factor, size factor, and book-to-market factor, but have different momentum factors. Fama-French momentum factor is constructed by using double sorting on firm size and stock momentum, whereas Carhart momentum factor is constructed by sorting stocks on momentum 
Table XI. Alternative asset pricing models

This table reports abnormal returns for equal- and value-weighted Democracy-Dictatorship hedge portfolios using alternative asset pricing models. In Panel A, the market (capital asset pricing model) model is employed to replace the Carhart four-factor model. In Panel B, the Fama-French four-factor model is used. The Fama-French momentum factor is downloaded from Kenneth French's website. In Panel C, we augment the Carhart four-factor model with the liquidity factor of Pastor and Stambaugh (2003) and estimate this five-factor model. In Panel D, we extend the Carhart four-factor model by the takeover factor of Cremers, Nair, and John (2009) and estimate this five-factor model. In all panels, we use the principal component of the three transparency proxies as a measure of transparency. The sample period ranges from September 1990 to December 1999. $t$-statistics are reported in parentheses under the estimation coefficient. The significance levels $1 \%, 5 \%$, and $10 \%$ are denoted by $* * *, * *$, and *, respectively.

\begin{tabular}{|c|c|c|c|c|c|}
\hline \multicolumn{3}{|c|}{ Equal-weighted hedge portfolio } & \multicolumn{3}{|c|}{ Value-weighted hedge portfolio } \\
\hline Lowest tercile & $\begin{array}{l}\text { Medium } \\
\text { tercile }\end{array}$ & $\begin{array}{l}\text { Highest } \\
\text { tercile }\end{array}$ & $\begin{array}{l}\text { Lowest } \\
\text { tercile }\end{array}$ & $\begin{array}{l}\text { Medium } \\
\text { tercile }\end{array}$ & $\begin{array}{l}\text { Highest } \\
\text { tercile }\end{array}$ \\
\hline \multicolumn{6}{|c|}{ Panel A: Market model } \\
\hline $\begin{array}{c}0.53^{*} \\
(1.68)\end{array}$ & $\begin{array}{c}-0.09 \\
(0.26)\end{array}$ & $\begin{array}{c}0.10 \\
(0.17)\end{array}$ & $\begin{array}{c}0.91^{*} \\
(1.95)\end{array}$ & $\begin{array}{c}0.76 \\
(1.67)\end{array}$ & $\begin{array}{c}-0.44 \\
(0.64)\end{array}$ \\
\hline \multicolumn{6}{|c|}{ Panel B: Fama-French four-factor model } \\
\hline $\begin{array}{l}0.66^{* *} \\
(2.41)\end{array}$ & $\begin{array}{c}-0.16 \\
(0.46)\end{array}$ & $\begin{array}{c}0.37 \\
(0.70)\end{array}$ & $\begin{array}{l}0.85^{* *} \\
(2.24)\end{array}$ & $\begin{array}{c}0.65 \\
(1.52)\end{array}$ & $\begin{array}{l}-0.31 \\
(0.45)\end{array}$ \\
\hline \multicolumn{6}{|c|}{ Panel C: Five-factor model including the liquidity factor } \\
\hline $\begin{array}{l}0.81^{* * *} \\
(2.66)\end{array}$ & $\begin{array}{c}0.07 \\
(0.19)\end{array}$ & $\begin{array}{c}0.58 \\
(1.05)\end{array}$ & $\begin{array}{l}1.11^{* *} \\
(2.56)\end{array}$ & $\begin{array}{c}0.73 \\
(1.62)\end{array}$ & $\begin{array}{c}-0.10 \\
(0.15)\end{array}$ \\
\hline \multicolumn{6}{|c|}{ Panel D: Five-factor model including the takeover factor } \\
\hline $\begin{array}{l}0.75^{* *} \\
(2.49)\end{array}$ & $\begin{array}{c}0.24 \\
(0.55)\end{array}$ & $\begin{array}{c}0.65 \\
(0.99)\end{array}$ & $\begin{array}{l}0.92^{* *} \\
(2.16)\end{array}$ & $\begin{array}{c}0.64 \\
(0.91)\end{array}$ & $\begin{array}{c}0.32 \\
(0.43)\end{array}$ \\
\hline
\end{tabular}

only. ${ }^{26}$ According to Panel B, this factor construction difference does not affect our results that much. We still obtain similar abnormal return patterns across the three transparency groups, although the magnitude of the alphas is smaller.

In Panel C, we augment the Carhart four-factor model with the liquidity factor of Pastor and Stambaugh (2003), who find that market-wide liquidity is an important asset pricing variable. As is shown in the table, adding this additional risk factor results in economically and statistically similar abnormal return patterns.

$\overline{26}$ The data for their momentum factor are obtained from Kenneth French's website. 
In Panel D, we extend the Carhart four-factor model by the takeover factor of Cremers, Nair, and John (2009), who construct this factor based on a target firm's takeover probability. ${ }^{27}$ Cremers, Nair, and John (2009) find that the abnormal returns to the Democracy-Dictatorship portfolio in GIM become insignificant when they include the takeover factor in the four-factor model. However, adding this additional factor does not fully explain our abnormal return patterns across transparency terciles. For example, the value-weighted alpha decreases from $1.10 \%(t$-statistic $=2.45)$ using Carhart four-factor model (see Panel B of Table V for this estimation result) to $0.92 \%$ ( $t$-statistic $=2.16$ ) using the extended five-factor model, suggesting that the takeover factor of Cremers, Nair, and John (2009) does explain part of the abnormal returns to the Democracy-Dictatorship portfolios. Since the alpha for the high transparency tercile remains positive and significant for both equaland value-weighted portfolios, we conclude that a firm's information environment creates another important dimension that matters for the way in which a firm's governance mechanism affects firm performance. Put differently, it is likely that a firm's information environment has an incremental impact on its takeover likelihood (see, e.g., Amel-Zadeh and Zhang, 2011; Marquardt and Zur, 2011; Martin and Shalev, 2011; McNichols and Stubben, 2011). Therefore, transparency might be an additional variable for gaging a firm's takeover probability, which might significantly enhance the takeover factor of Cremers, Nair, and John (2009).

\section{Governance, Firm Value, and Operating Performance}

To provide further evidence, we follow GIM and study the effect of corporate governance on firm value (i.e., Tobin's $Q$ ) and on measures of operating performance. While GIM examine these relations for all firms, Giroud and Mueller (2011) find that they are more pronounced for firms in noncompetitive industries. Here, we investigate whether the positive role of governance varies across firms with different transparency levels.

\subsection{GOVERNANCE, TRANSPARENCY, AND FIRM VALUE}

To study the relation between governance and firm value, we estimate the following model:

$Q_{\text {it }}=\alpha_{t}+\alpha_{j}+\beta_{1 t}\left(G_{\text {it }} \times A 1_{\text {it }}\right)+\beta_{2 t}\left(G_{\text {it }} \times A 2_{\text {it }}\right)+\beta_{3 t}\left(G_{\text {it }} \times A 3_{\text {it }}\right)+\gamma_{t} \mathbf{Z}_{\text {it }}+\epsilon_{\text {it }}$,

$\overline{27}$ We are grateful to Martijn Cremers for providing us with the takeover factor data. 
where $Q_{\mathrm{it}}$ is the industry-adjusted Tobin's $Q$ in year $t$ for firm $i, \alpha_{j}$ and $\alpha_{t}$ are industry and year fixed effects, $G_{\text {it }}$ is the G-index, $A 1_{\text {it }}$ is the dummy variable for the lowest tercile of analyst variable, $A 2_{\text {it }}$ is the dummy variable for the medium tercile of analyst variable, $A 3_{\text {it }}$ is the dummy variable for the highest tercile of analyst variable, $Z_{i t}$ is a set of control variables, including firm age (in logs), firm size (book value of assets, Compustat item \#6, in logs), S\&P 500 dummy, and a Delaware dummy. These are also the control variables used in GIM (2003). The control variables also include dummies of the analyst variables to account for the direct effect of the transparency terciles. Tobin's $Q$ is defined as the market value of assets divided by the book value of assets (item \#6). Market value of assets is calculated by using the sum of book value of assets (item \#6) and market value of common equity from Compustat (item $\# 24 \times$ item \#25) minus the sum of book value of common equity (item \#60) and balance sheet deferred taxes (item \#74). Industry-adjusted Tobin's $Q$ is calculated by adjusting firm's $Q$ by the industry median. Industry median is computed every year for each of the $48 \mathrm{FF}$ industries. The sample period is from 1990 to 2006 and the standard errors are clustered at the industry level.

Table XII contains our results for the panel regression. Column [1] reports the coefficient estimate from the regression of Tobin's $Q$ on G-index. The coefficient is -0.035 and highly significant $(t$-statistic $=2.75$ ), confirming the positive impact of corporate governance on firm value identified in the literature. In Column [2], we interact the G-index with forecast error dummies and report the coefficients for the interaction terms. Similar patterns as in our earlier tables appear: the absolute value of the coefficient is largest $(-0.095)$ and most significant $(t$-statistic $=3.35)$ in the transparent group, is smaller $(-0.023)$ and less significant $(t$-statistic $=2.60)$ in the medium group, and is smallest $(0.008)$ and insignificant $(t$-statistic $=1.06)$ in the opaque group. In Columns [3] and [4], we interact the G-index with forecast dispersion and revision volatility dummies, respectively. We also obtain monotonic patterns for these two transparency measures.

\subsection{GOVERNANCE, TRANSPARENCY, AND OPERATING PERFORMANCE}

To study the relation between governance and operating performance, we use the same regression specification as in Equation (4), but replace industry-adjusted Tobin's $Q$ by measures of firm performance: ROA, ROE, and NPM. ROA is defined as net income (item \#172) divided by the book value of assets (item \#6), ROE is defined as net income divided by the book value of common equity (item \#60), and NPM is defined as net income divided by sales (item \#12). All performance variables are industry-adjusted by subtracting the industry median from the performance 
Table XII. Governance, transparency, and firm value

This table reports the results from panel regressions of industry-adjusted Tobin's $Q$ on an intercept, year, and industry fixed effects, the G-index (or the interaction terms between the G-index and transparency dummies), firm size, firm age, S\&P 500 dummy, and Delaware dummy. The control variables also include transparency dummies to account for the direct effect of the transparency terciles. Tobin's $Q$ is the market value of assets divided by the book value of assets. Industry-adjusted Tobin's $Q$ is calculated by subtracting the industry median in a given FF industry and year. Firm size is the logarithm of firm assets. Column [1] reports the coefficient on G-index. Column [2] reports the coefficients on interaction terms when forecast error is used. Column [3] reports the coefficients on the interaction terms when forecast dispersion is used. Column [4] reports the coefficients on interaction terms when revision volatility is used. The sample period is from 1990 to 2006. $t$-statistics are reported in parentheses under the estimation coefficient. The significance level $1 \%$ is denoted by $* * *$.

\begin{tabular}{|c|c|c|c|c|}
\hline & [1] & [2] & [3] & [4] \\
\hline G-index & $-0.035^{* * *}(2.75)$ & & & \\
\hline G-index $\times$ lowest & & $-0.095^{* * *}(3.35)$ & $-0.110^{* * *}(3.70)$ & $-0.104 * * *(3.78)$ \\
\hline G-index $\times$ medium & & $-0.023 * * *(2.60)$ & $-0.009(1.31)$ & $-0.012(1.40)$ \\
\hline G-index $\times$ highest & & $0.008(1.06)$ & $0.008(0.71)$ & $0.006(0.54)$ \\
\hline Year-FE & Yes & Yes & Yes & Yes \\
\hline Industry-FE & Yes & Yes & Yes & Yes \\
\hline Number of Obs. & 12,792 & 12,792 & 12,792 & 12,792 \\
\hline Adj. $R^{2}$ & 0.07 & 0.14 & 0.18 & 0.18 \\
\hline
\end{tabular}

variable. Industry median is computed every year for each of the $48 \mathrm{FF}$ industries. All dependent variables are trimmed at the 5th and 95th percentiles of their empirical distribution. All explanatory variables are lagged. Following GIM, we include the logarithm of the book-to-market ratio in the previous year as an additional control variable. The sample period is from 1990 to 2006 and the standard errors are clustered at the industry level.

Table XIII contains our results for the panel regression. Columns [1-3] report the coefficients on the interaction terms when the dependent variable is ROA and transparency is measured by forecast error, forecast dispersion, and revision volatility, respectively. The coefficient on the interaction term for the dummy variable of the lowest tercile is always negative and statistically significant, whereas the coefficient on the interaction term for the dummy variable of the highest tercile is small and insignificant. For instance, in Column [1], the coefficient estimate for the G-index is large $(-0.182)$ and significant $(t$-statistic $=2.28)$ for the transparent group, and it is small $(0.007)$ and insignificant $(t$-statistic $=0.13)$ for the opaque group. In Columns [4-6], the dependent variable is NPM, and in Columns [7-9], the dependent variable is ROE. In both cases, we find similar patterns for the 
Table XIII. Governance, transparency, and operating performance

This table reports the results from panel regressions of industry-adjusted measures of operating performance on an intercept, year-, and industry fixed effects, the interaction terms between the G-index and transparency dummies, firm size, firm age, S\&P 500 dummy, Delaware dummy, and the logarithm of the book-to-market ratio. The control variables also include transparency dummies to account for the direct effect of the transparency terciles. Firm performance measure is either ROA, ROE, or NPM. ROA is defined as net income divided by the book value of assets (item \#6), ROE is defined as net income divided by the book value of common equity (item \#60), and NPM is defined as net income divided by sales (item \#12). All explanatory variables are lagged. All performance variables are industry-adjusted, which is calculated by subtracting the industry median from the variable. Industry median is computed every year for each of the $48 \mathrm{FF}$ industries. All dependent variables are trimmed at the 5th and 95th percentiles of their empirical distribution. Columns [1-3] report the coefficients when the dependent variable is ROA. Columns [4-6] report the coefficients when the dependent variable is ROE, and Columns [7-9] report the coefficients when the dependent variable is NPM. In Columns [1, 4, and 7], forecast error is used to measure transparency, in Columns [2, 5, and 8], forecast dispersion is used to measure transparency, and in columns [3, 6, and 9] revision volatility is used to measure transparency. FE, FD, and RV stand for forecast error, forecast dispersion, and revision volatility, respectively. All coefficients are multiplied by 100 . The sample period is from 1990 to 2006 and the standard errors are clustered at the industry level. $t$-statistics are reported in parentheses under the estimation coefficient. The significance levels $1 \%, 5 \%$, and $10 \%$ are denoted by $* * *, * *$, and *, respectively.

\begin{tabular}{|c|c|c|c|c|c|c|c|c|c|}
\hline & \multicolumn{3}{|c|}{ ROA } & \multicolumn{3}{|c|}{ NPM } & \multicolumn{3}{|c|}{ ROE } \\
\hline & [1] & {$[2]$} & [3] & [4] & [5] & [6] & [7] & {$[8]$} & [9] \\
\hline & $\mathrm{FE}$ & FD & RV & $\mathrm{FE}$ & FD & $\mathrm{RV}$ & $\mathrm{FE}$ & FD & $\mathrm{RV}$ \\
\hline G-index $\times$ lowest & $\begin{array}{l}-0.182 * * \\
(2.28)\end{array}$ & $\begin{array}{l}-0.219 * * * \\
(2.72)\end{array}$ & $\begin{array}{l}-0.226^{* * *} \\
(2.62)\end{array}$ & $\begin{array}{l}-0.393^{*} \\
(1.76)\end{array}$ & $\begin{array}{l}-0.411^{*} \\
(1.84)\end{array}$ & $\begin{aligned} & -0.397 * \\
& (1.86)\end{aligned}$ & $\begin{array}{l}-0.262^{* *} \\
(2.17)\end{array}$ & $\begin{array}{l}*-0.347 * * \\
(2.54)\end{array}$ & $\begin{array}{l}-0.369^{* * *} \\
(2.62)\end{array}$ \\
\hline G-index $\times$ medium & $\begin{array}{l}-0.082 \\
(1.36)\end{array}$ & $\begin{array}{c}-0.038 \\
(0.68)\end{array}$ & $\begin{array}{l}-0.058 \\
(1.00)\end{array}$ & $\begin{array}{l}-0.013 \\
(0.10)\end{array}$ & $\begin{array}{r}0.034 \\
(0.28)\end{array}$ & $\begin{array}{l}-0.076 \\
(0.54)\end{array}$ & $\begin{array}{r}-0.137 \\
(1.14)\end{array}$ & $\begin{array}{r}-0.131 \\
1.64)\end{array}$ & $\begin{array}{c}0.028 \\
(0.17)\end{array}$ \\
\hline G-index $\times$ highest & $\begin{array}{r}0.007 \\
(0.13)\end{array}$ & $\begin{array}{r}0.033 \\
(0.49)\end{array}$ & $\begin{array}{l}0.036 \\
(0.55)\end{array}$ & $\begin{array}{c}-0.17 \\
(1.61)\end{array}$ & $\begin{array}{c}-0.144 \\
(1.21)\end{array}$ & $\begin{array}{l}-0.104 \\
(0.76)\end{array}$ & $\begin{array}{l}0.136 \\
(1.06)\end{array}$ & $\begin{array}{r}0.279 \\
(1.31)\end{array}$ & $\begin{array}{c}0.092 \\
(0.78)\end{array}$ \\
\hline Year-FE & Yes & Yes & Yes & Yes & Yes & Yes & Yes & Yes & Yes \\
\hline Industry-FE & Yes & Yes & Yes & Yes & Yes & Yes & Yes & Yes & Yes \\
\hline Number of Obs. & 2,055 & 2,055 & 2,055 & 2,063 & 2,063 & 2,063 & 2,109 & 2,109 & 2,109 \\
\hline Adj. $R^{2}$ & 0.33 & 0.34 & 0.35 & 0.12 & 0.13 & 0.12 & 0.21 & 0.21 & 0.21 \\
\hline
\end{tabular}

coefficient estimates of all three transparency measures. That is, the coefficient of interest is negative and significant for transparent firms, and it is small and insignificant for opaque firms. This confirms the earlier finding that firms with better governance have better operating performance, and also reveals that the positive effect of governance is largely coming from transparent firms. 


\subsection{CAPITAL EXPENDITURE AND ACQUISITION ACTIVITY}

The results from our firm value and operating performance tests indicate that good governance firms are associated with higher firm value and higher operating performance. To gain a better understanding of the channels through which good governance in transparent firms create value, we follow the strategy of Giroud and Mueller (2011) to examine the relation between governance and investment activity. In particular, we use the same specification as in the operating performance regressions, except that the dependent variable is now either capital expenditures or some measure of acquisition activity. These additional estimation results are gathered in Table XIV.

In Columns [1-3], the dependent variable is capital expenditures (item \#128) scaled by total assets (item \#6). It is industry-adjusted by subtracting the industry median from the variable. Industry median is computed every year for each of the $48 \mathrm{FF}$ industries. The dependent variable is trimmed at the 5th and 95th percentiles of its empirical distribution. All explanatory variables are lagged. The sample period is from 1990 to 2006. As is shown, the coefficient on G-index is large and significant for the transparent group, and it is small and insignificant for the opaque group. For example, in Column [2], when transparency is measured by forecast dispersion, the coefficient is $0.044(t$-statistic $=2.36)$ for the transparent group, and it is $0.018(t$-statistic $=1.12)$ for the opaque group. This finding implies that good governance firms have less capital expenditures, on average, and this relation is more pronounced for transparent firms.

In Columns [4-12], we investigate the relation between governance and acquisition activity measured by acquisition ratio, acquisition count, and acquisition likelihood. Acquisition ratio is the sum of the value of all acquisitions made by a firm in a given year divided by the firm's market capitalization in that year. Acquisition count is the number of acquisitions made by a firm in a given year. Acquisition likelihood is a dummy variable that equals one if the number of acquisitions made by a firm in a given year is nonzero and zero otherwise. These variables are constructed using data from the Securities Data Corporation's database. As is displayed in the table, the coefficient on G-index is always large and significant for the transparent group, and it is smaller and insignificant or marginally significant for the opaque group. This evidence suggests that weak governance firms make more acquisitions, but this relation exists only for the transparent group. In other words, transparent firms with good governance make less acquisition. 


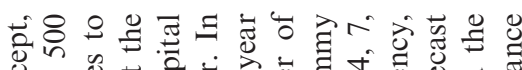

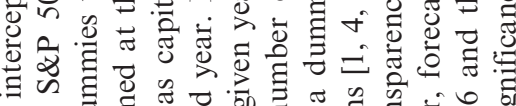

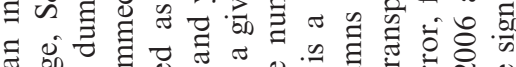

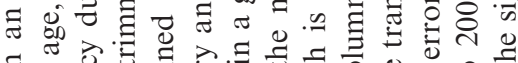
5

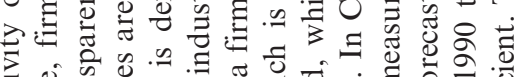

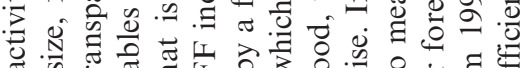

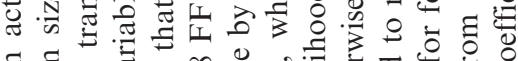

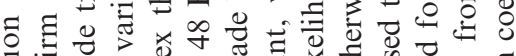

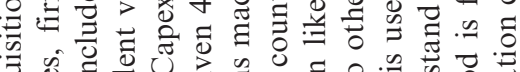
焉.

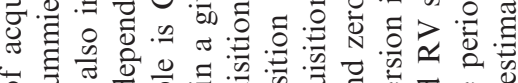
的言

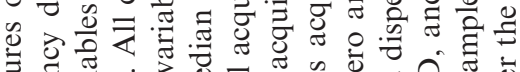

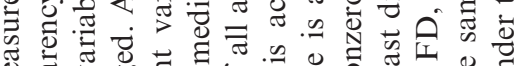

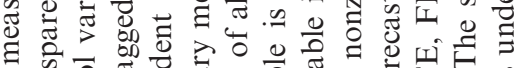

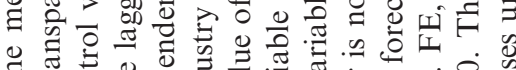

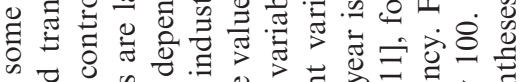

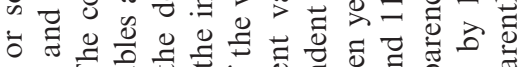

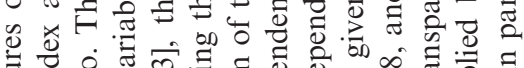

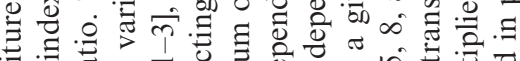

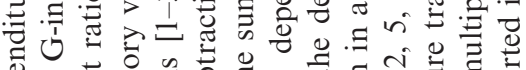

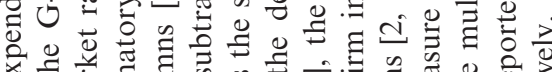

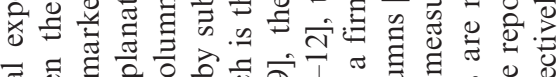

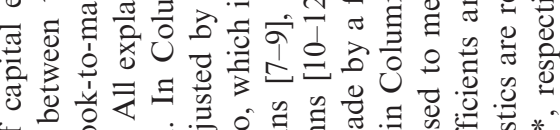

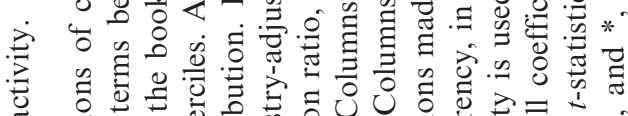

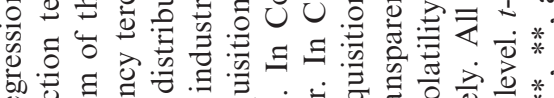

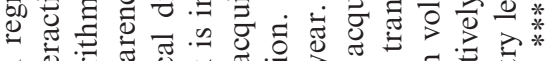
Q

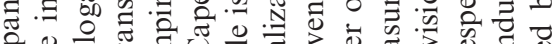
20을

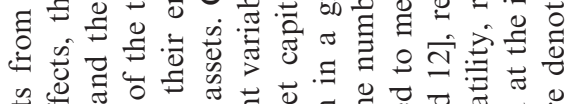
능

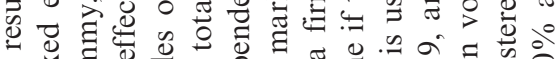
造造言

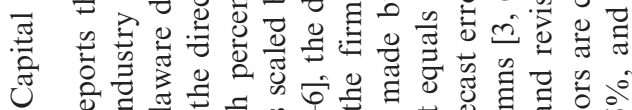
厄 흔. 要

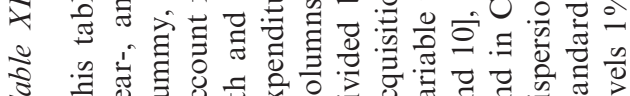

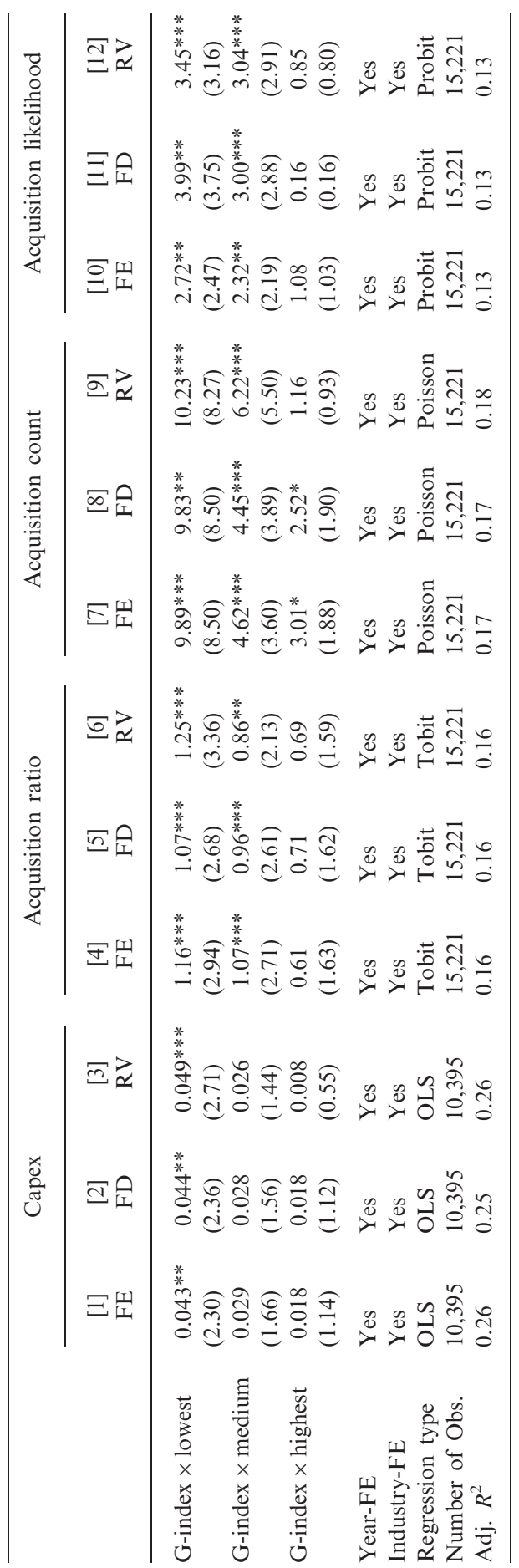


Considerable evidence in the literature shows the existence of negative announcement return and negative abnormal performance by acquiring firms. This evidence together with our investment activity test results suggest that good governance in transparent firms creates value by reducing agency costs. This provides a possible explanation for the pattern across transparency groups that we consistently find in our firm value, operating performance, and stock return tests.

\section{Conclusion}

Since, Jensen and Meckling (1976), economists have devoted much effort to studying a firm's governance and a firm's information environment. Recent cases of poor governance as, e.g., in the scandals of Enron or Worldcom, have lead legislators to mandate rules that enforce more transparency, suggesting governance and transparency are substitutes. However, this is not clear theoretically, since there are compelling arguments for governance and transparency to be complements or substitutes. This article aims at providing an empirical answer to the following question: are firms with better governance (measured by a lower G-index) associated with better performance, on average, if they are also more transparent (e.g., measured by forecast dispersion)?

In essence, we document a complementary effect between transparency and governance by showing that the Democracy-Dictatorship hedge portfolio is associated with significantly positive abnormal returns when firms are transparent, whereas the hedge portfolio earns no abnormal return when firms are opaque. The positive effect of good corporate governance on stock returns is larger than that reported in GIM. For example, using the 1st principal component to combine the information of forecast error, forecast dispersion, and revision volatility, the hedge portfolio formed on this principal component earns a monthly abnormal return of $1.37 \%$ for value-weighted $(1.28 \%$ for equal-weighted) portfolios, which is nearly twice as large as the alpha in the full sample. We also find that good governance firms, as measured by the G-index, have higher firm value and higher operating performance, but only among transparent firms. When we examine the channels through which good governance in transparent firms creates value, we find that good governance firms make less inefficient investments and less value-destroying acquisitions, but again mainly when they are also transparent firms.

Our findings suggest several broader issues. First, they suggest for corporate managers that firms thus far may have failed to recognize the 
complementarity of governance and transparency. Hence, when firms improve their governance, they could also improve their disclosure policy to perhaps benefit more from improved governance. Second, academic researchers, who study the impact of corporate policies on equity returns, could benefit from recognizing a firm's information environment, because transparency could also be independently important for amplifying other corporate policies' effect on firm performance. Third, this study hints at improving transparency (by, e.g., the Regulation Fair Disclosure in 2000 or the Sarbanes-Oxley Act of 2002) might help policy-makers to accomplish better firm performance, while focusing on governance alone might not accomplish this goal. Finally, the subtle interaction of governance and transparency that influences equity prices (or performance) that we document is not yet fully understood theoretically. These issues should also be fruitful for future research.

\section{References}

Amel-Zadeh, A. and Zhang, Y. (2011) The economic consequences of financial reporting quality for the market for corporate control: Evidence from financial restatements, Unpublished working paper, Columbia University.

Armstrong, C. S., Balakrishnana, K., and Cohen, D. (2012) Corporate governance and the information environment: Evidence from state antitakeover laws, Journal of Accounting and Economics 53, 185-204.

Bebchuk, L. A., Cohen, A., and Ferrell, A. (2009) What matters in corporate governance? Review of Financial Studies 22, 783-827.

Bebchuk, L. A., Cohen, A., and Wang, C. (2011) Learning and the disappearing association between governance and returns, Journal of Financial Economics, forthcoming.

Bond, P., Edmans, A., and Goldstein, I. (2012) The real effects of financial markets, Annual Reviews of Financial Economics, forthcoming.

Botosan, C. A. and Plumlee, M. A. (2002) A re-examination of disclosure level and expected cost of equity capital, Journal of Accounting Research 40, 21-40.

Bushman, R., Piotroski, J. D., and Smith, A. A. (2004) What determines corporate transparency? Journal of Accounting Research 42, 207-252.

Carhart, M. M. (1997) On persistence in mutual fund performance, Journal of Finance 52, $57-82$.

Core, J. E., Guay, W. R., and Rusticus, T. O. (2006) Does weak governance cause weak stock returns? An examination of firm operating performance and investors expectations, Journal of Finance 61, 655-687.

Cremers, M. K. J. and Nair, V. B. (2005) Governance mechanisms and equity prices, Journal of Finance 60, 2859-2894.

Cremers, M. K. J., Nair, V. B., and John, K. (2009) Takeovers and the cross-section of returns, Review of Financial Studies 22, 1409-1445.

Cremers, M. K. J., Nair, V. B., and Peyer, U. (2008) Takeover defenses and competition, Journal of Empirical Legal Studies 5, 791-818. 
Dechow, P. M. and Dichev, I. D. (2002) The quality of accruals and earnings: The role of accrual estimation errors, The Accounting Review 77(Suppl.), 35-59.

Demsetz, H. and Lehn, K. (1985) The structure of corporate ownership: Causes and consequences, Journal of Political Economy 93, 1155-1177.

Doidge, C., Karolyi, A., and Stulz, R. M. (2007) Why do countries matter so much for corporate governance?, Journal of Financial Economics 86, 1-39.

Duchin, R., Matsusaka, J., and Ozbas, O. (2010) When are outside directors effective?, Journal of Financial Economics 96, 195-214.

Easterwood, J. C. and Nutt, S. R. (1999) Inefficiency in analysts' earnings forecasts: Systematic misreaction or systematic optimism? Journal of Finance 54, 1777-1797.

Fama, E. F. and French, K. R. (1997) Industry costs of capital, Journal of Financial Economics 43, 153-193.

Ferreira, M. A. and Laux, P. A. (2007) Corporate governance, idiosyncratic risk, and information flow, Journal of Finance 62, 951-989.

Fishman, M.J. and Hagerty, K.M. (1989) Disclosure decisions by firms and the competition for price efficiency, Journal of Finance 44, 633-646.

Francis, J., LaFond, R., Olsson, P., and Schipper, K. (2005) The market pricing of accruals quality, Journal of Accounting and Economics 39, 295-327.

Giroud, X. and Mueller, H.M. (2011) Corporate governance, product market competition, and equity prices, Journal of Finance 66, 563-600.

Givoly, D. and Lakonishok, J. (1979) The information content of financial analysts' forecasts of earnings, Journal of Accounting Research 1, 165-185.

Gompers, P. A., Ishii, J. L., and Metrick, A. (2001) Corporate governance and equity prices Working paper No. 8449, National Bureau of Economic Research.

Gompers, P. A., Ishii, J. L., and Metrick, A. (2003) Corporate governance and equity prices, Quarterly Journal of Economics 118, 107-155.

Gu, L. (2012) Transparency, takeover likelihood, and the cross-section of stock returns, Unpublished working paper, University of Illinois.

Hail, L. and Leuz, C. (2009) Cost of capital effects and changes in growth expectations around U.S. cross-listings, Journal of Financial Economics 93, 428-454.

Hand, J. R. M. (2003) Profits, losses and the nonlinear pricing of internet stocks, in: J. R. M. Hand and B. Lev (eds), Intangible Assets: Values, Measures and Risks, Oxford University Press, Oxford.

Harris, M. and Raviv, A. (1998) Capital budgeting and delegation, Journal of Financial Economics 50, 259-289.

Harris, M. and Raviv, A. (2010) Control of corporate decisions: Shareholders vs. management, The Review of Financial Studies 23, 4115-4147.

Hermalin, B. E. and Weisbach, M. S. (1988) The determinants of board composition, RAND Journal of Economics 19, 589-606.

Hermalin, B. E. and Weisbach, M. S. (2007) Transparency and corporate governance, Working paper No. 12875, National Bureau of Economic Research.

Hou, K. and Robinson, D. T. (2006) Industry concentration and average stock returns, Journal of Finance 61, 1927-1956.

Jensen, M. C. and Meckling, W. H. (1976) Theory of the firm: Managerial behavior, agency costs and ownership structure, Journal of Financial Economics 3, 305-360.

Lang, M. H. and Lundholm, R. J. (1996) Corporate disclosure policy and analyst behavior, Accounting Review 71, 467-492. 
Lang, M. H., Lins, K. V., and Maffett, M. (2012) Transparency, liquidity, and valuation: International evidence on when transparency matters most, Journal of accounting research 50, 729-774.

Larcker, D. F., Richardson, S. A., and Tuna, I. (2007) Corporate governance, accounting outcomes, and organizational performance, Accounting Review 82, 963-1008.

Leuz, C. and Oberholzer, F. (2006) Political relationships, global financing, and corporate transparency: Evidence from Indonesia, Journal of Financial Economics 81, 411-439.

Leuz, C. and Verrecchia, R. E. (2000) The economic consequences of increased disclosure, Journal of Accounting Research 38, 91-124.

Lim, T. (2001) Rationality and analysts' forecast bias, Journal of Finance 56, 369-385.

Marquardt, C. A. and Zur, E. (2011) The role of accounting quality in the M\&A market, Unpublished working paper, Baruch College.

Martin, X. and Shalev, R. (2011) Target firm-specific information and expected synergies in acquisitions, Unpublished working paper, Washington University in St. Louis.

McNichols, M. F. (2002) Discussion of the quality of accruals and earnings: The role of accrual estimation errors, The Accounting Review 77(Suppl.), 61-69.

McNichols, M. F. and Stubben, S. (2011) The effect of target-firm accounting quality on valuation in acquisitions, Unpublished working paper, Stanford University.

Mukherjee, A. (2011) Are control rights valuable when shareholders lack information? Unpublished working paper, Hong Kong University of Science and Technology.

Novaes, W. (1995) Capital structure choice when managers are in control: Entrenchment versus efficiency, Journal of Business 76, 49-82.

Pastor, L. and Stambaugh, R. F. (2003) Liquidity risk and expected stock returns, Journal of Political Economy 111, 642-685.

Paul, J. M. (1992) On the efficiency of stock-based compensation, Review Financial Studies 5, 471-502.

Shleifer, A. and Vishny, R. (1997) A survey of corporate governance, Journal of Finance 52, 737-783.

Singh, R. and Yerramilli, V. (2009) Can transparency be too much of a good thing? Unpublished working paper, University of Minnesota.

Stulz, R. M. (1988) Managerial control of voting rights: Financing policies and the market for corporate control, Journal of Financial Economics 20, 25-54.

Teoh, S. H. and Wong, T. J. (2002) Why new issues and high-accrual firms underperform: The role of analysts' credulity, Review of Financial Studies 15, 869-900.

Thomas, S. (2002) Firm diversification and asymmetric information: Evidence from analysts' forecasts and earnings announcements, Journal of Financial Economics 64, 373-396.

Zhang, X. F. (2006) Information uncertainty and stock returns, Journal of Finance 61, $105-137$.

Zwiebel, J. (1996) Dynamic capital structure under managerial entrenchment, American Economic Review 86, 1197-1215. 
